Frank Kalter \& Julia H. Schroedter

\title{
Transnational marriage among former labour migrants in Germany
}

\section{Transnationale Ehen von ehemaligen Arbeitsmigranten in Deutschland}

\begin{abstract}
:
In this paper we make use of data from the official statistics to analyze transnational marriage among immigrants in Germany. Pooling all currently available Scientific Use Files of the German Microcensus between 1976 and 2004, we are able to contribute empirical findings that are unique in their scope and their degree of differentiation. We look at the five most common groups of former labour migrants and study group-specific trends over generations and time. Our empirical analysis is guided by four basic expectations, which are anchored in a more general theoretical framework of immigrants' marriage behaviour. We find, as expected, large group differences in the propensity to select a spouse from one's own country of origin. Assumed effects of the opportunity structure, however, can only be confirmed for women. Central derivations from a general assimilationist view are also only partly supported: A general increase in transnational marriages among ex-Yugoslav and Turkish women over marriage cohorts, and the absence of any effects of structural assimilation on the propensity toward transnational marriages are the most puzzling results.
\end{abstract}

Key words: transnational marriage, social integration, marriage behaviour of migrants, German Microcensus

\section{Zusammenfassung:}

In diesem Beitrag verwenden wir Daten der amtlichen Statistik, um transnationale Ehen bei Immigranten in Deutschland zu analysieren. Die Zusammenführung aller verfügbaren Scientific Use Files des deutschen Mikrozenus zwischen 1976 und 2004 liefert empirische Befunde, die in ihrer Breite und in der Tiefe ihrer Differenzierung bislang einzigartig sind. Wir betrachten die fünf am weitesten verbreiteten Gruppen ehemaliger Arbeitsmigranten und untersuchen gruppenspezifische Trends über die Generationen und über die Zeit. Unsere empirische Analyse wird von vier Grundannahmen geleitet, die in einem allgemeineren theoretischen Rahmen des Heiratsverhaltens von Migranten verankert sind. Wie erwartet finden wir hinsichtlich der Neigung, eine(n) Partner(in) aus dem jeweils eigenen Herkunftsland zu wählen, große Unterschiede zwischen den Gruppen. Die vermuteten Effekte der Opportunitätsstruktur werden jedoch nur für die Frauen bestätigt. Zentrale Schlussfolgerungen aus einer allgemein assimilationistischen Sichtweise zeigen sich ebenfalls nur teilweise: $\mathrm{Zu}$ den erstaunlichsten Ergebnissen unserer Studie gehören die allgemeine Zunahme transnationaler Ehen von Frauen aus dem ehemaligen Jugoslawien und der Türkei sowie die Abwesenheit von Effekten der strukturellen Assimilation auf die Neigung zur transnationalen Ehe.

Schlagwörter: transnationale Ehen, soziale Integration, Heiratsverhalten von Migranten, Mikrozensus 


\section{Introduction ${ }^{1}$}

Although the marriage behaviour of immigrants and their descendants is commonly seen as a key dimension of integration (Alba/Golden 1986; Gordon 1964; Lieberson/Waters 1988; Pagnini/Morgan 1990), research on the situation in Germany has been surprisingly scarce. Within the few empirical studies that recently became available, the focus is mainly on intermarriage, i.e., marriage to native Germans (Haug 2004, 2006; Klein 2001; Nauck 2007; Schroedter 2006; Schroedter/Kalter 2008). Little is known, however, on the phenomenon of transnational marriage, meaning marriage of an immigrant in Germany to a spouse residing in the country of origin. There is some scattered evidence that especially among Turks, transnational partner choice is an empirically important option (Janßen/ Polat 2006: 47f; Schroedter 2006; Straßburger 2001, 2003), and occasional case-studies deliver helpful insights into individual motivations and situational conditions behind transnational partner choice (Aydin 2003; Straßburger 2001, 2003). Due to a lack of adequate large-scale data, however, sophisticated multivariate analyses were not possible for a long time. Only recently, González-Ferrer (2006) presented a first, more systematic approach relying on data of the German Socio-economic Panel (GSOEP).

Fortunately, in recent years an additional source of promising data arose: The German Microcensus has become widely available to social scientists, and Scientific Use Files have been produced for many years. Relying on this information it is now possible to study the marriage patterns among immigrants in Germany over a period of almost 30 years. In this paper we utilize these data to study transnational marriage behaviour and its causes in detail. More precisely, we are interested in differences among the five most common groups of former labour migrants, i.e., Italians, Spaniards, Greeks, ex-Yugoslavs, and Turks, and in group-specific trends over generations and time. We aim not only at a thorough description of these differences and trends, but we also test, as far as the data allow, whether basic theoretical mechanisms of immigrants' partner choice can account for them. In particular, we investigate the role of opportunity structures and of structural integration. We thus complement the earlier, survey-based findings of González-Ferrer (2006) by evidence from official data, and, given the sample size of our data set, enrich them by more fine-grained analyses in several respects.

The paper is structured as follows: We start with a discussion of theoretical approaches to immigrants' marriage behaviour, trying to deduce potential mechanisms underlying their choice of a transnational spouse (2.). We sketch a rather general framework and try to derive hypotheses on the specific phenomenon of transnational marriage choice by labour migrants in Germany. Within these discussions we pay specific attention to group differences, trends over generations and cohorts, the role of opportunity structures, and immigrants' integration into other spheres of life, especially structural integration. Afterwards, we describe the data structure and the relevant variables used in our analyses (3.). We then proceed to present the major results (4.). We report group differences and trends in transnational marriages, and test our leading hypotheses using multinomial logit

1 We would like to thank the guest editor, Irena Kogan, as well as two anonymous reviewers for helpful comments on an earlier version of this paper. 
analyses. We conclude with a short summary of our most important findings and a discussion of subsequent research questions (5.).

\section{Theory, hypotheses, and past research}

While intermarriage is usually seen as a crucial indicator of social assimilation (Alba/Golden 1986; Gordon 1964; Lieberson/Waters 1990), which goes along with a successful general integration into the receiving country, transnational marriage is often understood as representing the opposite end of the same scale: Selecting one's partner from one's own country of origin is assumed to reflect strong orientations towards its norms and values, and weak bonds to the country of residence (Hooghiemstra 2001; Lievens 1999). Many, although not all, available arguments regarding the likelihood of transnational marriages thus arise as kind of reverse-versions of respective arguments on intermarriage. Therefore, it is helpful to start with a more general theoretical framework of immigrants' marriage behaviour, which in parallel refers to intermarriage, in order to understand potential mechanisms underlying the phenomenon of transnational marriage. This is done in the first of the following two sections (2.1). In the second section (2.2), we then try to formulate basic expectations that will guide our empirical analysis. They are derived from these general considerations regarding the specific immigration context in Germany. We also briefly discuss what empirical evidence for these expectations is now available.

\subsection{General theories of immigrants' mate selection}

In the literature on the marriage behaviour of immigrants, three basic strands of argument can be distinguished: arguments that focus on individual preferences, on influences of the social group, and on structural restrictions in the marriage market (Kalmijn 1991, 1998; Lieberson/Waters 1988). According to the first, the selection of a spouse is decisively affected by the preferences of an individual for specific characteristics in a mate. Among these characteristics, socioeconomic resources play an important role. Hence, individuals who have successfully accumulated these resources - i.e., a high level of education, income, and prestige - are seen to be especially attractive partners. Assuming that both partners want to maximize the socioeconomic status of their spouse, mechanisms of the marriage market are expected to lead to a high degree of homogeneity between the partners (Kalmijn 1998; Laitner 1991). From this general reasoning it is usually concluded that intermarriage will be more likely if the education level of an immigrant is high, as in many contexts natives tend to have higher mean levels of education. By the same token, one could argue that transnational marriages are more likely if the education level of an immigrant is low, as in many contexts the level of education in the country of origin is lower than that in the receiving country. Some authors have additionally argued that socioeconomic resources might also be exchanged for other goods (Merton 2000 [1941]). Accordingly, one could expect better educated immigrants to marry less educated natives in exchange for ethnicity, or less educated immigrants to marry better educated people in the country of origin in exchange for place of residence. 
But individual preferences are not directed towards socio-economic resources alone. Rather, they are also guided by the rewarding character of the interaction itself. Usually, interaction is more rewarding if values and opinions as well as life styles, i.e., cultural resources of the interacting persons, are similar. The basic need for social recognition can be supplied more easily and cost-efficiently in a context of shared opinions and beliefs than in a context of diverging attitudes (Kalmijn 1998). Accordingly, a certain degree of cultural similarity promotes the establishment of long-term relationships. In the context of immigration one would therefore expect a higher inclination toward intermarriage if the level of cognitive and cultural assimilation to the receiving country is high, but a higher inclination toward transnational marriages if the level of cognitive and cultural assimilation is low.

The second starting point is the influence of the social group to which an individual belongs. Most obviously, if ethnic groups have specific expectations regarding the marriage behaviour of their members, like norms of ethnic endogamy, and if the group is a major source of social approval to the individual, this should result in barriers towards intermarriage (Hooghiemstra 2001; Kalmijn 1998). Norms of endogamy can be part of religious belief systems (Coleman 1994: 113; Reniers 2001). The actual strength of religious norms in partner selection depends on the religiosity of an individual. The most important social group that might be involved in the marriage decision of an immigrant is the family. Especially for individuals who are closely bound to family or kinship, family agreement with a potential spouse is of major relevance, and possible sanctions exercised by the family are avoided. According to some authors, a transnational marriage between kin might be a strategy of the family of origin to preserve the economic capital within the family (Aydin 2003: 251; Reniers 2001). In addition, relatives or family members in the country of origin are in a better position to exert pressure to marry off one of their children to a potential partner in Germany (or another western European country) than are nonrelatives (Böcker 1994; Reniers 2001; Straßburger 2003: 276).

Third, the opportunity structure of the marriage market has a fundamental impact on the selection of a spouse: Who does not meet, does not mate (Blau 1994). Opportunities for contact are provided by the spatial context, on the one hand, and by affiliation to social groups, on the other hand (Blau 1994; Blau et al. 1984). If ethnic groups are very small or if they suffer from a strongly unbalanced sex ratio (or marriage squeeze), immigrants who are looking for a spouse will possibly intermarry, even if there is a strong preference for an ethnically homogeneous marriage. Another alternative in this case might be to enlarge the marriage market to include the immigrants' country of origin. This option is likely to be used especially if immigrants still have friends or relatives in their home country. Thus, the existence of transnational social networks is expected to promote transnational marriages. Opportunities often tend to be restricted to highly selective social foci, which determine individuals' chances to meet in the first place and to maintain a relationship afterwards (Feld 1981, 1984). Here, educational institutions, workplaces, and neighbourhoods have been shown to be important contexts (Kalmijn/Flap 2001; Model/ Fisher 2002). Generally, the higher the ethnic segregation of these focal places, the lower is the probability of intermarriage. This is a further reason why the likelihood that immigrants will marry into the autochthonous population is assumed to increase with the degree of structural assimilation. 


\subsection{Leading hypotheses and previous empirical evidence}

In this section, we will try to transform the described general mechanisms into more precise hypotheses about the propensity to marry a partner from the country of origin versus a co-national immigrant or versus an autochthonous partner. We will pay attention to the specific situation of groups of former labour migrants in Germany and briefly discuss previous empirical findings, where available. We concentrate on four basic expectations.

First, following the reasoning in the general theoretical approaches, one can expect pronounced differences between different labour migrant groups in Germany. For example, the degree of structural assimilation is known to vary largely between groups, Turks being clearly the most disadvantaged (Alba et al. 1994; Granato/Kalter 2001; Kalter/Granato 2007; Kalter et al. 2007; Kristen/Granato 2007). Among the five nationalities under consideration, they also show the largest cultural distance. In most of the cases they are of Muslim denomination, which holds also for immigrants from some parts of ex-Yugoslavia, showing a relatively high religiosity (Gostomski 2008). This includes rules of endogamy, most notably for Muslim women, which results in relatively low levels of intermarriage (Haug 2004; Schroedter/Kalter 2008). While these conclusions mainly rely on the mechanisms of preference and group influence discussed in Section 2.1, an additional important aspect fostering especially the transnational type of an intraethnic marriage is found on the demand side: Turkey and all but one of the countries formerly constituting Yugoslavia do not belong to the European Union. Therefore, the influx from these countries is subject to restrictive German immigration laws, unlike that from Italy, Greece, and Spain, whose citizens, being EU citizens, are granted unrestricted mobility and right of residence. For non-EU-foreigners who wish to migrate to Germany and do not have close family members already there, marrying a resident of Germany has been virtually the only way to gain legal entry since the stop of recruitment in 1973. In case of marriage to a German, an EU citizen, or to an immigrant possessing a full employment permit, the partner from abroad also obtains temporary residence and an employment permit. As a result, a transnational marriage may serve as a means to circumvent restrictive immigration policies (Beck-Gernsheim 2006; Hooghiemstra 2001). For several reasons, one would therefore expect that especially Turks, and on a lower level also ex-Yugoslavs, are more likely to be engaged in transnational marriages than the other labour migrant groups in Germany. This conclusion is supported by available empirical findings (Gonzáles-Ferrrer 2006; Janßen/ Polat 2006; Kreienbrink/Rühl 2007: 44ff; Schroedter 2006; Straßburger 2001, 2003). Indepth studies further suggest that especially the group-influence mechanism seems to be important. Marriages among Turkish immigrants are often between relatives, e.g., between cousins, and tight family relations and transnational marriages seem closely associated (Aydin 2003; Böcker 1994; Gestring et al. 2006; Haug 2004; Reniers 2001). It is argued that due to a different 'marriage regime' that is primarily characterized by an intergenerational solidarity, the family has an especially high influence on the marriage decision of Turks (Nauck 2001). Among Turkish immigrants a marriage decision is often seen as a family matter rather than as an individual decision, and arranged marriages are still common (Aydin 2003: 271f; Beck-Gernsheim 2006: 116f; Timmerman 2006: 126).

Second, it would be reasonable to assume that the tendency toward transnational marriages will decline over generations and time (marriage cohorts). As argued in the 
general theoretical discussion (see the preference mechanism), the relative attractiveness of partners from the country of origin tends to be negatively related to one's own degree of assimilation into the receiving society. There is overwhelming evidence that for labour migrant groups in Germany, like for most immigrant groups all over the world, there is a clear trend towards assimilation over generations in most central sub-dimensions of integration, like language (Esser 2008), education (Alba et al. 1994), labour market success (Kalter/Granato 2007), residential areas (Janßen/Schroedter 2007), and also cultural orientations and preferences (Diehl/Schnell 2006; Gerhards/Hans 2009). There is also evidence that net of trends over generations, there are also trends over time (Kalter/Granato 2002; Kalter et al. 2007). However, it is important to note that there are also essential exceptions to this pattern, e.g., religion and religiosity, where the general diagnosis of intergenerational assimilation (in this case: secularization) does not seem to hold for Turkish immigrants (Diehl/König 2009). In our previous study focussing on intermarriage (Schroedter/Kalter 2008), we did not find a significant difference between first- and secondgeneration Turks of either sex. It will therefore be very interesting to see how this appears with respect to transnational marriages. Gonzáles-Ferrer (2006) reports insignificant generation effects and no clear trend over marriage cohorts. Due to sample size, however, she was not able to differentiate generations and cohort effects for ethnic groups separately.

Third, we expect the opportunity structure in the marriage market for co-ethnic marriages in the receiving country to have an impact on the propensity toward transnational marriages. More precisely, we hypothesize that the larger the size of an ethnic group in Germany, the smaller should be the incentive for its members to choose a partner from their country of origin. And, the more favourable the sex ratio (opposite sex vs. one's own sex) of the ethnic group in the host society, the more likely should attractive candidates be available without having to cross the border. The predictions on the effect of both structural variables on transnational marriage thus parallel those on intermarriage with equal signs, as both are formulated in contrast to the comparison group of co-ethnic immigrant partners living in Germany. In the literature, the size of an immigrant group, as well as its sex ratio, have proved to be empirically important for intermarriage in many contexts (Hwang et al. 1997; Lieberson/Waters 1988; Lievens 1998; Pagnini/Morgan 1990; Tubergen/Maas 2007; Wildsmith et al. 2003), including Germany (Haug 2004; Klein 2001; Schroedter/Kalter 2008). With respect to transnational marriages, González-Ferrer (2006) finds strong support, at least for the sex ratio, that it works in the expected direction.

Fourth, one would expect that the propensity toward a transnational marriage choice is negatively correlated to structural integration into the receiving society. As outlined in the last section, this follows from the preference mechanism as well as from the idea that social foci provide important opportunity structures. Again, there is ample evidence for the impact of education in the case of intermarriage, for which, with the same basic arguments, a general positive correlation is hypothesized. Especially education has been shown to be positively linked to intermarriage (Fu/Heaton 2008; Kalmijn/Tubergen 2006; Tubergen/Maas 2007; Schroedter/Kalter 2008; Qian 1997; Wildsmith et al. 2003). However, evidence is less clear that the expected reverse signs show up when looking at transnational marriage. Gonzáles-Ferrer (2006) can confirm this hypothesis only for men but not for women, which she finds one of her most puzzling results. A possible explanation for this fact is formulated by Lievens (1999) for women from cultures with a strong pa- 
trilocal tradition: A woman who marries, so he argues, is expected to become a full member of her husband's family; she owes obedience to her mother-in-law and often the new couple lives with the parents of the husband for a while. A transnational marriage could be a mean, especially for highly educated women, to elude the direct influence of the inlaws. Furthermore, the traditional balance of power between husband and wife might be shifted to the woman's advantage: She is the one who knows how things work in the receiving society, has the necessary cultural resources, and offers a potential partner the opportunity to migrate if desired. In this respect, a woman could gain a lot from this marriage type, and the involved costs are low since 'such a marriage is fully accepted or even preferred by her parents' (Lievens 1999: 728). Gonzáles-Ferrer (2006), however, cannot find any support for this hypothesis when running additional analyses with the GSOEP data.

\section{Data and Methods}

In our empirical analyses we use data from the German Microcensus, which is an annual official obligatory survey comprising one percent of the resident population. In the meantime, Scientific Use Files are available for many years, each consisting of a factually anonymized $70 \%$-subsample. For our analyses we pool data from all currently available Scientific Use Files between 1976 and $2004 .^{2}$ This provides us with a large number of cases in a trend design and thus with a unique possibility to study immigrants' patterns of marriage over time.

We restrict our sample to the five major groups of former labour migrants and their descendants, i.e., Italians, Spaniards, Greeks, ex-Yugoslavs, and Turks. The definition of these groups has to rely on citizenship because the Microcensus did not ask for parents' country of birth until 2004. To avoid confounding the trends by German reunification and its aftermath, in all years we select only those members of these groups who were living in the Western part of Germany. For the purposes of our analysis, we choose only those immigrants who are married, and who were either born in Germany or had been living there for at least five years prior to their marriage. This restriction is made to ensure that the country of residence was part of the individuals' marriage market at the time of their marriage decision. Immigrants who had been staying in the host country for a shorter period prior to their marriage might already have had a partner or fiancé(e) in their country of origin, so that their partner choice actually took place before immigration.

Our dependent variable distinguishes between four types of marriage, according to the nationality of the spouse and, where required, his or her country of residence before marriage. More precisely, the variable includes the following categories: (1) Transna-

2 These are 19 datasets altogether, including the years 1976, 1978, 1980, 1982, 1985, 1987, 1989, 1991, 1993, and all years between 1995 and 2004. Note that the Microcensus is designed as a rotating panel in which every year one quarter of the selected households is renewed. As a consequence, there is a possible overlap of respondents in consecutive years. To account for this fact, we apply a design weight that weights each year with the inverse of the expected value of how often a household contained in this year is counted in total. 
tional marriage is defined as marriage to a co-national partner, who immigrated either in the year of the marriage or thereafter. ${ }^{3}$ (2) Intramarriage is all other marriage to a partner of the same national origin. (3) Intermarriage is marriage to an autochthonous, i.e., German, partner. Again, we have to rely on citizenship, which is a drawback of our data inasmuch as the conditions of and inclination toward naturalization changed during the period under study. ${ }^{4}$ We also subsume persons with dual citizenship (German and a foreign one) as 'German partners'. (4) The remaining category is marriage between someone whose spouse has a nationality different from their own but other than German.

Besides nationality, we differentiate immigrants by generation, distinguishing between the first generation, the 1.5 generation, and the second generation. Immigrants of the first generation are defined as those coming to Germany after the age of 16, whereas the 1.5 generation consists of immigrants who arrived between the ages of 7 to 16 . The second generation refers to those non-nationals who either arrived in Germany before the beginning of compulsory schooling (age 6) or were born in Germany. To account for possible interactions of nationality and generation, we construct 15 subgroups, combining both variables.

We include two macro level variables to control for variation in the composition of the ethnic minority groups over time: relative group size and relative sex ratio. Both variables represent the opportunity structure in Germany one year prior to marriage. The group size is the relative population size (expressed in percentages) of a given nationality among the nonmarried population in total. It is constructed age-specifically regarding the population in the age range five years younger, respectively older, than the respondent. To account for the fact that husbands are on average three years older than their wives, the mean of the interval is adjusted by -3 or +3 years when counting the population of the opposite sex. The sex ratio contrasts the sex imbalance of each nationality with that of the remaining population. This is done by taking the ratio (own group versus remaining population) of the respective sex ratios (opposite sex versus own sex). Again, the figures are calculated for the non-married population within the above-mentioned 11-year age intervals for both sexes. The information for the sex ratio and the population size were generated with non-weighted Microcensus data from 1962 to 2004 and were merged to the respondents by year of marriage, nationality and age at marriage. ${ }^{5}$ Both sex ratio and relative group size relate to the entire federal territory (Western Germany) and thus represent rather crude measures of the actual availability of potential partners. Nevertheless, at least for the Netherlands, van Tubergen

3 Please note that this is a somewhat arbitrary criterion as there is no clear timing between the marriage and the immigration of the 'transnational partner'. We decided to choose a rather conservative operational definition, which might underestimate the actual number of transnational marriages.

4 The German citizenship law is one of the most restrictive in the EU. Before 1991, naturalization was almost not possible. Since 1991, migrants have been able to apply for naturalization after a minimum stay of 15 years in Germany (and the fulfilment of further conditions). In 2000, the legislation on naturalization was reformed entirely: The preconditions for naturalization were simplified (e.g., a reduction to 8 years of residence) and, furthermore, aspects of the 'ius soli' were integrated into the concept of naturalization so that - under certain conditions - children of foreign parents obtain German citizenship by birth.

5 Because the nationality of Greek, Turkish and Yugoslavian immigrants is not declared separately in the Microcensus data from 1962 to 1969, the rates of these nationalities could be generated only for years from 1973 onwards. Due to absent Microcensus years, we had to merge years of marriages for which no information was available with the information of the closest available (possibly previous) year. 
and Maas (2007) showed that the effects of relative group size and sex ratio on ethnic intermarriage do not vary much on the local (municipality) or on the national level.

On the individual level, our central independent variable is educational attainment. It is measured according to the updated version of the educational classification CASMIN (Brauns/Steinmann 1999). Altogether, we differentiate ten categories, including a category for persons who are still in school. Persons who have not completed any education are subsumed under those for whom information on education is missing. This was necessary due to modifications in the survey questions on education during different Microcensus years (Schroedter 2008: 21f). Note that in our data, education is measured at the time of the survey and not, as would be preferable, at the time of marriage. We think, however, that resulting biases will only be small; massive change in educational attainment (in terms of CASMIN) tends to be a rare event after marriage.

Further control variables are marriage cohort and age at marriage. All analyses are conducted separately for men and women. The sample sizes vary for descriptive and multivariate analysis due to missing values and excluded categories. For men, the weighted number of cases amounts to 9,679 resp. 9,238 (unweighted: 25,597 resp. 24,269), for women to 5,985 resp. 5,634 (unweighted: 16,228 resp. 15,189). Descriptive statistics for the variables used in our empirical analysis can be found in Tables $4 \mathrm{a}$ and $4 \mathrm{~b}$ in the appendix.

When interpreting the results of the empirical analyses below, one should keep in mind that despite all advantages and merits, there is a basic shortcoming to the German Microcensus data. Like all studies that rely on data collected in the receiving country only, there can deliver information only on those marriages of immigrants in Germany where both partners decided to live on in Germany afterwards. This is unlikely to happen at random. On the contrary, there is reason to believe that this holds especially for the transnational type, and tendentially is more likely if the immigrant residing in Germany is female. So, there is probably some selection bias in the sample when referring to a target population of all immigrants who marry while living in Germany.

\section{Results}

The presentation of our empirical analyses is subdivided into three subsections. First, we will report some descriptive results showing the main trends of transnational marriages over generations and marriage cohorts. Then, we test in how far these trends can be explained by changes in opportunity structures and changes in the educational attainment of the immigrants living in Germany. While the second section concentrates on group and generation differences, accounting only for an overall trend over time, the third section looks at group-specific trends.

\subsection{Transnational marriage in Germany: Occurrence, group differences, and trends}

Table 1a reports the marriage patterns among male immigrants in Germany according to the pooled Microcensus data. In total, about a third (33.2\%) of all marriages is of the 
transnational type. Choosing a co-national partner living in Germany is the prevailing strategy $(40.8 \%)$, while bi-national marriage to a German wife ranks third $(23.0 \%)$ and wives with other nationality play only a minor role (3.1\%). Differentiating by nationality, there are large differences between groups. Transnational marriage is the most frequent type among male Turkish immigrants, making up almost half of all cases within this group. The transnational type is of considerable, albeit lower, importance also among exYugoslavs, while Italian, Spanish, and Greek immigrants rarely choose a wife from their country of origin. We find that in most of the cases Italian and Spanish men are even married to German wives.

Differentiating further by generations, we find a notable decline in the prevalence of transnational marriages from the first to the second generation for all five groups. The pattern is clear and especially pronounced among Italians and Spaniards, for whom the rate is modest in the first generation (20.6\%, resp. $21.1 \%)$, even lower in the 1.5 generation $(15.9 \%$, resp. $10.1 \%)$, and almost negligible in the second generation $(4.6 \%$, resp. $3.3 \%)$. Among Greeks, the drop from the first to the second generation is of a comparable magnitude (20.2\% to $8.8 \%$ ); however, the 1.5 generation behaves similarly $(20.8 \%)$ to the first. Among Turks and ex-Yugoslavs there is also no decline between the first generation ( $48.9 \%$, resp. $30.3 \%$ ) and the 1.5 generation (54.8\%, resp. 31.2\%); however, even in these two groups a decline, albeit on a much higher level, from the 1.5 generation to the second generation $(35.9 \%$, resp. $20.9 \%)$ is clearly visible.

Table 1a: Nationality of spouse and type of marriage of male migrants by nationality and generation (row percentages)

\begin{tabular}{|c|c|c|c|c|c|c|}
\hline \multirow{2}{*}{\multicolumn{2}{|c|}{$\begin{array}{l}\text { Nationality \& generation } \\
\text { (husband) }\end{array}$}} & \multicolumn{2}{|c|}{ Same nationality (wife) } & \multicolumn{2}{|c|}{ Other nationality } & \multirow[b]{2}{*}{$\mathbf{N}$} \\
\hline & & Transnational & $\begin{array}{l}\text { Co-national } \\
\text { immigrant }\end{array}$ & German & Other & \\
\hline \multirow[t]{4}{*}{ Italian } & $1^{\text {st }}$ gen. & 20.6 & 29.5 & 45.1 & 4.9 & 1,507 \\
\hline & 1.5 gen. & 15.9 & 41.2 & 39.2 & 3.7 & 698 \\
\hline & $2^{\text {nd }}$ gen. & 4.6 & 37.0 & 50.5 & 7.8 & 349 \\
\hline & Total & 17.1 & 33.7 & 44.2 & 5.0 & 2,553 \\
\hline \multirow[t]{4}{*}{ Spanish } & $1^{\text {st }}$ gen & 21.1 & 37.3 & 34.0 & 7.6 & 240 \\
\hline & 1.5 gen. & 10.1 & 44.5 & 42.3 & 3.1 & 114 \\
\hline & $2^{\text {nd }}$ gen. & 3.3 & 31.4 & 60.1 & 5.3 & 87 \\
\hline & Total & 14.8 & 38.0 & 41.3 & 6.0 & 441 \\
\hline \multirow[t]{4}{*}{ Greek } & $1^{\text {st }}$ gen. & 20.2 & 51.3 & 24.2 & 4.3 & 475 \\
\hline & 1.5 gen. & 20.8 & 58.8 & 16.9 & 3.5 & 257 \\
\hline & $2^{\text {nd }}$ gen. & 8.8 & 53.0 & 29.1 & 9.2 & 164 \\
\hline & Total & 18.3 & 53.8 & 23.0 & 5.0 & 896 \\
\hline \multirow[t]{4}{*}{ Turkish } & $1^{\text {st }}$ gen. & 48.9 & 36.8 & 12.8 & 1.5 & 1,209 \\
\hline & 1.5 gen. & 54.8 & 38.5 & 5.6 & 1.0 & 2,134 \\
\hline & $2^{\text {nd }}$ gen. & 35.9 & 52.2 & 10.5 & 1.4 & 991 \\
\hline & Total & 48.9 & 41.2 & 8.7 & 1.2 & 4,333 \\
\hline \multirow[t]{4}{*}{ ex-Yugoslav } & $1^{\text {st }}$ gen. & 30.3 & 46.2 & 20.6 & 3.0 & 1,057 \\
\hline & 1.5 gen. & 31.2 & 39.7 & 25.9 & 3.1 & 242 \\
\hline & $2^{\text {nd }}$ gen. & 20.9 & 45.2 & 29.8 & 4.0 & 157 \\
\hline & Total & 29.4 & 45.0 & 22.5 & 3.2 & 1,456 \\
\hline Total & & 33.2 & 40.8 & 23.0 & 3.1 & 9,679 \\
\hline
\end{tabular}

Source: Microcensus Scientific Use Files 1976-2004 (19 files) 
As Table $1 \mathrm{~b}$ shows, the picture is very different when turning to the marriage behaviour of female immigrants in Germany. Most notably, a transnational choice of husband is much less common than a transnational choice of wife. In total, only 18.0 percent of all immigrant women in Germany select their marriage partner from their own country of origin. Transnational marriages are very rare events among Italian and Spanish women and also not very common among Greeks and ex-Yugoslavs. Turkish women show by far the highest share (31.2\%). Surprisingly, there is no clear pattern of decline over generations for any of the groups. By and large, with some minor variations, the marriage patterns among female immigrants in Germany seem to be independent of generational status.

Table 1b: Nationality of spouse and type of marriage of female migrants by nationality and generation (row percentages)

\begin{tabular}{|c|c|c|c|c|c|c|}
\hline \multirow{2}{*}{\multicolumn{2}{|c|}{$\begin{array}{l}\text { Nationality \& Generation } \\
\text { (wife) }\end{array}$}} & \multicolumn{2}{|c|}{ Same nationality (husband) } & \multicolumn{2}{|c|}{ Other nationality } & \multirow[b]{2}{*}{$\mathbf{N}$} \\
\hline & & Transnational & $\begin{array}{l}\text { Co-national } \\
\text { immigrant }\end{array}$ & German & Other & \\
\hline \multirow[t]{4}{*}{ Italian } & $1^{\text {st }}$ gen. & 1.7 & 66.3 & 25.7 & 6.3 & 196 \\
\hline & 1.5 gen. & 2.6 & 80.5 & 14.1 & 2.8 & 501 \\
\hline & $2^{\text {nd }}$ gen. & 3.0 & 63.5 & 27.1 & 6.5 & 439 \\
\hline & Total & 2.6 & 71.5 & 21.1 & 4.8 & 1,136 \\
\hline \multirow[t]{4}{*}{ Spanish } & $1^{\text {st }}$ gen. & 0.7 & 58.4 & 30.3 & 10.7 & 100 \\
\hline & 1.5 gen. & 1.4 & 60.0 & 30.8 & 7.9 & 97 \\
\hline & $2^{\text {nd }}$ gen. & 0.3 & 39.0 & 47.1 & 13.6 & 97 \\
\hline & Total & 0.8 & 52.5 & 36.0 & 10.7 & 294 \\
\hline \multirow[t]{4}{*}{ Greek } & $1^{\text {st }}$ gen. & 2.3 & 68.8 & 22.7 & 6.2 & 154 \\
\hline & 1.5 gen. & 12.5 & 69.9 & 12.9 & 4.8 & 238 \\
\hline & $2^{\text {nd }}$ gen. & 7.8 & 70.7 & 14.9 & 6.6 & 224 \\
\hline & Total & 8.2 & 69.9 & 16.1 & 5.8 & 616 \\
\hline \multirow[t]{4}{*}{ Turkish } & $1^{\text {st }}$ gen. & 24.7 & 60.0 & 12.7 & 2.6 & 355 \\
\hline & 1.5 gen. & 36.1 & 60.2 & 2.7 & 1.1 & 1,420 \\
\hline & $2^{\text {nd }}$ gen. & 27.0 & 66.0 & 5.7 & 1.4 & 1069 \\
\hline & Total & 31.2 & 62.4 & 5.1 & 1.4 & 2,844 \\
\hline \multirow[t]{4}{*}{ ex-Yugoslav } & $1^{\text {st }}$ gen. & 5.4 & 57.3 & 31.8 & 5.4 & 595 \\
\hline & 1.5 gen. & 14.7 & 55.6 & 24.4 & 5.3 & 282 \\
\hline & $2^{\text {nd }}$ gen. & 16.2 & 51.6 & 25.8 & 6.5 & 218 \\
\hline & Total & 9.9 & 55.8 & 28.7 & 5.6 & 1,095 \\
\hline Total & & 18.0 & 63.2 & 15.1 & 3.7 & 5985 \\
\hline
\end{tabular}

Source: Microcensus Scientific Use Files 1976-2004 (19 files)

Beyond trends of transnational marriages over generations, we are interested in trends over time. Figure 1 displays the percentage of transnational marriages for each nationality over the marriage cohorts 1965 to 2000, separately for men and women. For men, the graphs indicate a slight decline among all groups except ex-Yugoslavs. The decline is pronounced and happened almost steadily among Italians, Spaniards, and Greeks. Turkish migrants, as already shown in Table 1a, have by far the highest percentage of transnational wives throughout all cohorts. For marriage cohorts 1971 and later, ex-Yugoslavs rank second. Even in the younger marriage cohorts, over 40 percent of the marriages among Turkish migrants are transnational, while among the ex-Yugoslav migrants the rates in the younger cohorts vary between 20 and 30 percent. 
Figure 1: Trends of transnational marriages of different immigrant groups over marriage cohorts (five-year moving average), in percentages

a. Men

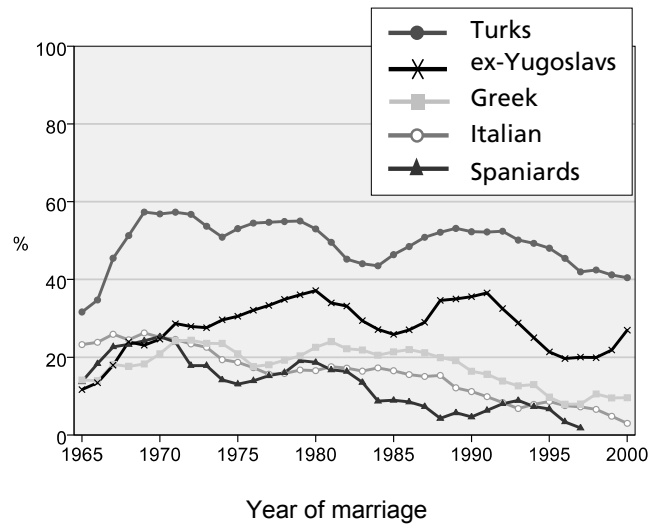

b. Women

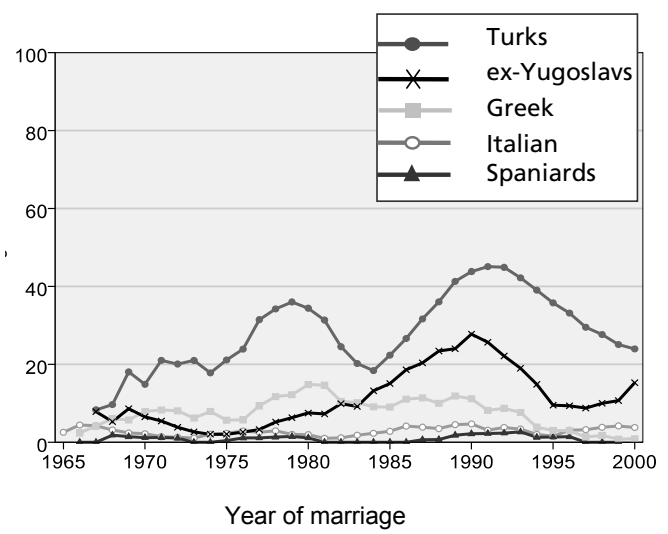

Source: Microcensus Scientific Use Files 1976-2004 (19 files)

Figure $1 \mathrm{~b}$ presents the propensity towards transnational marriage over marriage cohorts for women. We find that that the trends are less clear than in the case of men. The trend among the Turkish females is especially eye-catching. After an increase from 8 percent in 1965 to 36 percent in 1979, the rate dropped sharply to 18 percent again in 1984, rising to 45 percent in 1991, before continuously declining afterwards to 24 percent in 2000 . Among ex-Yugoslav women we monitor a continuous increase in transnational marriages from 2 percent in 1974 to 28 percent in 1990, before the figures begin to decrease to 9 percent in 1996, slightly rising again in the youngest marriage cohorts. Among Italian or Spanish women transnational marriages never played an important role at all: Between the marriage cohorts 1965 to 2000, their quotas never surmounted 5 percent. Greek females also indicate low probabilities of transnational marriages; after a peak in 1980 $(15 \%)$; the percentage has been continuously decreasing, amounting to less than 1 percent in the marriage cohort 2000.

\subsection{Multivariate analyses of group and generation differences}

In this section we apply multivariate models to analyze the likelihood of choosing a particular type of marriage among the different types. More precisely, we rely on multinomial logistic regression models using a dependent variable that has three possible values: transnational marriage, bi-national marriage to a German partner, and marriage to a conational migrant. The latter serves as the baseline category. Marriages to partners of other nationalities, the fourth type distinguished in Tables $1 \mathrm{a}$ and $1 \mathrm{~b}$, are neglected and treated as missing values. We study the effect of variables that are related to the theoretical mechanisms and hypotheses discussed above (see Section 2) and which are available in the Microcensus data (see Section 3). We run separate analyses for the sub-samples of immigrant men and immigrant women. 
Table 2a: Multinomial logit coefficients for type of marriage

(ref. marriage with co-national) of male immigrants

\begin{tabular}{|c|c|c|c|c|c|c|}
\hline & \multicolumn{2}{|c|}{ Model 1} & \multicolumn{2}{|c|}{ Model 2} & \multicolumn{2}{|c|}{ Model 3} \\
\hline & B & SE & B & SE & B & SE \\
\hline \multicolumn{7}{|c|}{ Transnational marriage (wife from own country of origin) } \\
\hline \multicolumn{7}{|c|}{\begin{tabular}{l|l} 
Group (ref. Turkish 1.5 gen.) &
\end{tabular}} \\
\hline Italian $1^{\text {st }}$ gen. & $-0.81^{* * *}$ & 0.10 & $-0.67^{* \star *}$ & 0.13 & $-0.67^{* \star *}$ & 0.13 \\
\hline Italian 1.5 gen. & $-1.35^{\star \star *}$ & 0.12 & $-1.15^{\star \star \star}$ & 0.14 & $-1.15^{\star \star \star}$ & 0.14 \\
\hline Italian $2^{\text {nd }}$ gen. & $-2.37^{* * *}$ & 0.27 & $-2.16^{\star * *}$ & 0.28 & $-2.14^{\star * *}$ & 0.28 \\
\hline Spanish $1^{\text {st }}$ gen. & $-1.04^{* * *}$ & 0.19 & $-0.84^{* * *}$ & 0.20 & $-0.84^{* \star *}$ & 0.20 \\
\hline Spanish 1.5 gen. & $-1.88^{* * *}$ & 0.33 & $-1.59^{\star * *}$ & 0.34 & $-1.57^{\star \star *}$ & 0.34 \\
\hline Spanish $2^{\text {nd }}$ gen. & $-2.61^{* * *}$ & 0.62 & $-2.30^{* * *}$ & 0.63 & $-2.27^{* * *}$ & 0.63 \\
\hline Greek $1^{\text {st }}$ gen. & $-1.41^{* * *}$ & 0.14 & $-1.26^{\star * *}$ & 0.15 & $-1.24^{* * *}$ & 0.15 \\
\hline Greek 1.5 gen. & $-1.42^{* \star *}$ & 0.17 & $-1.16^{\star \star *}$ & 0.18 & $-1.15^{\star * *}$ & 0.18 \\
\hline Greek $2^{\text {nd }}$ gen. & $-2.02^{\star \star \star}$ & 0.29 & $-1.73^{\star \star \star}$ & 0.30 & $-1.71^{\star \star *}$ & 0.30 \\
\hline Turkish $1^{\text {st }}$ gen. & -0.17 & 0.09 & -0.09 & 0.10 & -0.07 & 0.10 \\
\hline Turkish $2^{\text {nd }}$ gen. & $-0.56^{\star \star \star}$ & 0.09 & $-0.70^{\star \star \star}$ & 0.09 & $-0.69^{\star \star *}$ & 0.09 \\
\hline ex-Yugoslav $1^{\text {st }}$ gen. & $-0.88^{\star * *}$ & 0.10 & $-0.86^{\star \star \star}$ & 0.10 & $-0.83^{\star \star \star}$ & 0.10 \\
\hline ex-Yugoslav 1.5 gen. & $-0.61^{* * *}$ & 0.16 & $-0.39^{*}$ & 0.17 & $-0.37^{*}$ & 0.17 \\
\hline ex-Yugoslav $2^{\text {nd }}$ gen. & $-0.95^{\star \star *}$ & 0.22 & $-0.79^{\star \star \star}$ & 0.23 & $-0.76^{\star \star *}$ & 0.23 \\
\hline Age at marriage (cent. $27 \mathrm{yrs}$.) & 0.01 & 0.00 & $0.02^{\star *}$ & 0.00 & $0.01^{* *}$ & 0.00 \\
\hline Marriage cohort (cent. 1985) & -0.00 & 0.00 & $-0.01^{*}$ & 0.00 & $-0.01^{*}$ & 0.00 \\
\hline Rel. group size & & & $0.18^{* * *}$ & 0.04 & $0.17^{* * *}$ & 0.04 \\
\hline Rel. sex ratio & & & 0.10 & 0.10 & 0.09 & 0.10 \\
\hline \multicolumn{7}{|l|}{ Education (ref.1b) } \\
\hline Not applicable \& no education & & & & & -0.03 & 0.08 \\
\hline 1c (basic voc. training) & & & & & $-0.12^{*}$ & 0.06 \\
\hline $2 \mathrm{~b}$ (intermediate general) & & & & & -0.06 & 0.16 \\
\hline 2a (intermediate voc.) & & & & & -0.01 & 0.10 \\
\hline 2c_gen (general maturity) & & & & & -0.09 & 0.23 \\
\hline 2c_voc (voc. maturity) & & & & & -0.19 & 0.18 \\
\hline 3a (lower tertiary) & & & & & -0.39 & 0.29 \\
\hline $3 \mathrm{~b}$ (higher tertiary) & & & & & -0.37 & 0.27 \\
\hline Still in school & & & & & -0.21 & 0.25 \\
\hline Constant & $0.40^{\star * *}$ & 0.05 & -0.03 & 0.15 & 0.02 & 0.15 \\
\hline \multicolumn{7}{|c|}{ Bi-national marriage to a German wife } \\
\hline Group (ref. Turkish 1.5 gen.) & & & & & & \\
\hline Italian $1^{\text {st }}$ gen. & $2.11^{\star \star \star *}$ & 0.13 & $1.61^{* \star *}$ & 0.16 & $1.65^{\star \star \star}$ & 0.16 \\
\hline Italian 1.5 gen. & $1.84^{* * *}$ & 0.13 & $1.35^{\star * *}$ & 0.16 & $1.43^{\star \star *}$ & 0.16 \\
\hline Italian $2^{\text {nd }}$ gen. & $2.14^{\star \star *}$ & 0.16 & $1.70^{\star \star *}$ & 0.18 & $1.62^{\star \star *}$ & 0.18 \\
\hline Spanish $1^{\text {st }}$ gen. & $1.54^{* * *}$ & 0.20 & $1.02^{\star * *}$ & 0.22 & $0.99^{\star \star *}$ & 0.22 \\
\hline Spanish 1.5 gen. & $1.85^{\star \star \star}$ & 0.23 & $1.36^{\star \star \star}$ & 0.25 & $1.25^{\star \star \star}$ & 0.25 \\
\hline Spanish $2^{\text {nd }}$ gen. & $2.38^{* * *}$ & 0.26 & $2.00^{* * *}$ & 0.28 & $1.78^{\star \star *}$ & 0.28 \\
\hline Greek $1^{\text {st }}$ gen. & $0.81^{* * *}$ & 0.17 & $0.43^{*}$ & 0.18 & 0.26 & 0.18 \\
\hline Greek 1.5 gen. & $0.60^{* *}$ & 0.20 & 0.22 & 0.22 & 0.14 & 0.22 \\
\hline Greek $2^{\text {nd }}$ gen. & $1.25^{\star \star \star}$ & 0.21 & $0.83^{\star \star \star}$ & 0.23 & $0.61^{*}$ & 0.24 \\
\hline Turkish $1^{\text {st }}$ gen. & $0.42^{* *}$ & 0.15 & 0.22 & 0.15 & 0.10 & 0.16 \\
\hline Turkish $2^{\text {nd }}$ gen. & 0.28 & 0.15 & $0.44^{* *}$ & 0.16 & 0.31 & 0.17 \\
\hline ex-Yugoslav $1^{\text {st }}$ gen. & $0.68^{\star \star \star}$ & 0.14 & $0.64^{* * *}$ & 0.14 & $0.44^{* *}$ & 0.15 \\
\hline ex-Yugoslav 1.5 gen. & $1.39^{* \star *}$ & 0.19 & $1.15^{\star \star *}$ & 0.20 & $1.05^{\star \star *}$ & 0.20 \\
\hline ex-Yugoslav $2^{\text {nd }}$ gen. & $1.38^{* * *}$ & 0.23 & $1.23^{* * *}$ & 0.23 & $0.99^{* \star *}$ & 0.24 \\
\hline Age at marriage (cent. $27 \mathrm{yrs}$.) & $0.04^{* * *}$ & 0.00 & $0.04^{* * *}$ & 0.00 & $0.04^{\star \star *}$ & 0.01 \\
\hline Marriage cohort (cent. 1985) & $0.01^{* *}$ & 0.00 & $0.02^{* * *}$ & 0.00 & $0.01^{* *}$ & 0.00 \\
\hline
\end{tabular}




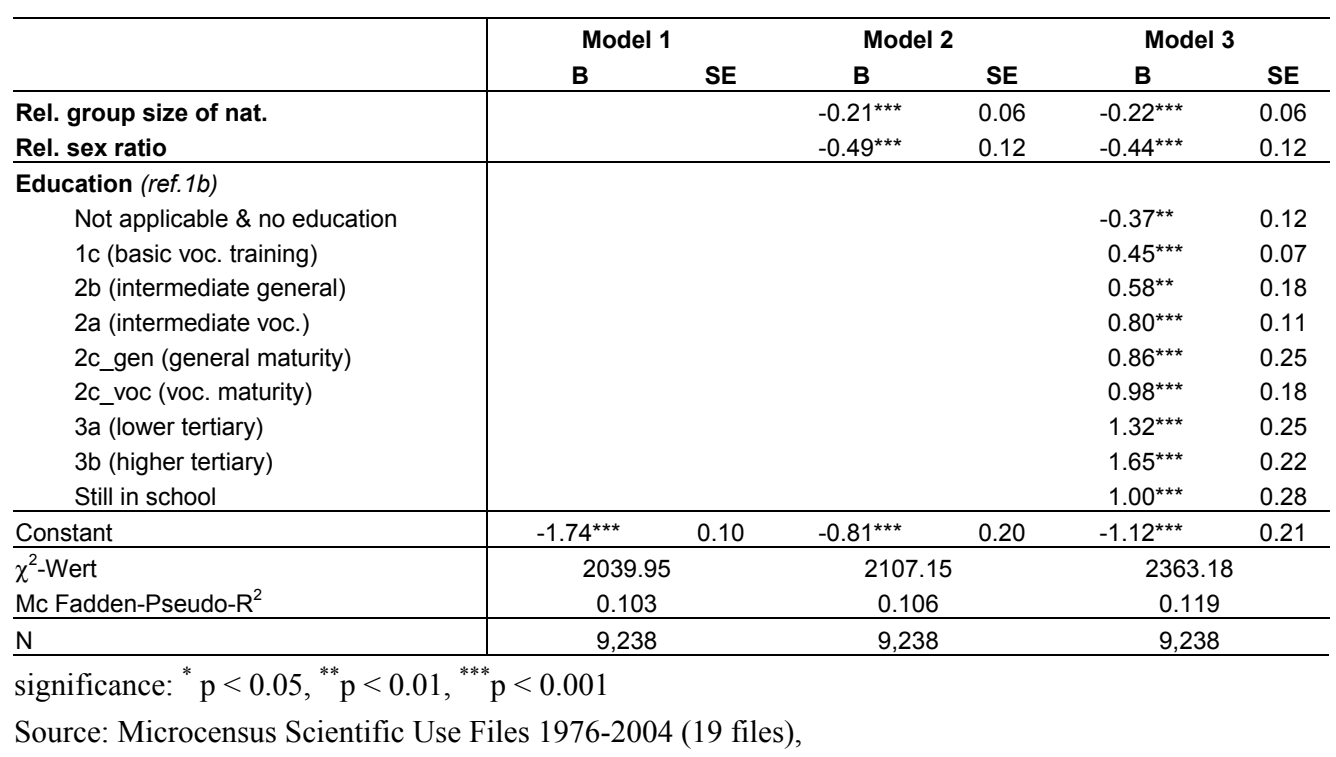

Table 2a reports log-odds effects and their standard errors from different models for men. Model 1 only includes the variables for various groups by generation, along with controls for age and year of marriage. In principle, the estimates reproduce the basic findings from Table 1a. As Turkish men of the 1.5 generation have the highest shares of transnational marriages, they serve as the reference category. Accordingly, in Model 1 all other categories have lower odds of choosing a transnational vs. a co-national immigrant wife. Except for those of Turks of the first generation, all coefficients are significantly different from zero. For Italians, Spanish, and Greek male immigrants the odds of choosing a wife from the home country decreases from the first generation over the 1.5 generation to the second generation. Looking at the standard errors, we find that the differences between the first and second generation are significant for all groups except ex-Yugoslavs. Neither of the two control variables has a significant effect. In particular, the coefficient of year of marriage is almost zero, meaning that there is no underlying overall trend in transnational marriages once we control for groups and generations.

Addressing the odds of bi-national marriage to a German (vs. co-national marriage), it turns out that all coefficients for groups by generations are positive, meaning that Turks of the 1.5 generation, the reference category, have the lowest odds of choosing a German wife. The patterns between generations within groups are not clearly shaped. The differences between groups, however, are remarkable: As was already shown in Table 1a, Italian and Spanish male immigrants choose German wives relatively often, Greek and exYugoslavs follow on a lower level, and of all groups, Turks clearly have the lowest rates of intermarriage to Germans. Immigrant men who marry German wives are somewhat older than those who marry co-national wives, and, very importantly, net of all group-bygeneration differences, we can detect a significant positive trend towards bi-national marriage over marriage cohorts.

In Model 2, two macro level variables are added to control for the group-specific opportunity structure in the marriage market. Let us start by discussing the sub-model for bi- 
national marriage first, where we find that both coefficients are significantly negative. This is in accordance with the theoretical assumptions: The larger the size of a national group in the receiving society and the higher the relative share of females within the national group, the larger is the supply of co-national marriage partners (the baseline category), and the lower, accordingly, the odds of choosing a German wife. When we compare the effects for nationality-by-generation categories to those in Model 1, we find that most of them are notably smaller. Thus, the opportunity structure can partly explain group and generation differences in bi-national marriage. It is also interesting to see that the effect of marriage increases from Model 1 to Model 2, meaning that accounting for the opportunity structure (getting 'better') over time, the positive trend towards a bi-national marriage choice by labour migrants in Germany is even more pronounced. Looking at the sub-model for transnational marriage, however, the picture is less clear and theoryconform. Neither structural variable shows the negative effects to be expected but rather positive signs, even significant in the case of group sizes. And, control of both variables also leads only to minor changes in the strength of the groups-by-generation effects.

Model 3 includes the level of educational attainment, and we find that this variable can also hardly account for the group and generation differences in transnational marriage choice. As compared to Model 2, the group-by-generation coefficients remain more or less unchanged. This is obviously due to the fact that education has almost no impact at all on the odds of choosing a partner from one's own country of origin. In the coefficients for different categories of the CASMIN scheme there is at most a very slight tendency that males with higher levels of education, esp. with tertiary education, are less likely to have a transnational wife; however, by and large, coefficients do not differ significantly. Accordingly, the theoretical expectation that the relative chances of transnational marriage decrease with the increasing level of educational attainment is not confirmed. In contrast, education is clearly important when looking at the odds of bi-national marriage. As theoretically expected, the higher their qualifications, the more likely are immigrant men to choose a German vs. a co-national wife. In spite of this fact, different degrees in educational attainment cannot explain existing group and generation differences in binational marriage choice very well, as the group-by-generation coefficients do not change considerably between Model 2 and Model 3. It is worth noting, however, that the effect of marriage cohort lessens notably when controlling for education in Model 3. So, structural educational assimilation over cohorts seems to explain part of the trend towards higher intermarriage rates.

Table $2 \mathrm{~b}$ reports the corresponding results of the different models for women. Let us start here by discussing the whole upper part first, meaning the sub-models on the odds of marrying a partner from one's own country of origin versus a co-national immigrant. Model 1 shows the log-odds effects for nationality-by-group categories. We find that compared to the reference category of 1.5-generation Turks, almost all groups are less likely to marry a transnational partner. This largely reflects the descriptive findings in Table $1 \mathrm{~b}$ above. Only Turks of the first generation show slightly higher odds, now that age at marriage and marriage cohort are controlled for. In accordance with Table $1 \mathrm{~b}$, we further see that in contrast to the findings for men, for all of the groups there is no clear trend over generations: Surprisingly, only Turkish women show significantly lower odds of having a transnational husband in the second generation as compared to the first generation. Note 
that both control variables are highly significant in the case of females. The older a woman, the less likely is she to marry someone from her country of origin (relative to a conational living in Germany). And, most importantly, net of the group-by-generation differences, we detect a positive overall trend over marriage cohorts.

Table 2b: Multinomial logit coefficients for type of marriage

(ref. marriage with co-national) of female immigrants

\begin{tabular}{|c|c|c|c|c|c|c|}
\hline & \multicolumn{2}{|c|}{ Model 1} & \multicolumn{2}{|c|}{ Model 2} & \multicolumn{2}{|c|}{ Model 3} \\
\hline & B & SE & B & SE & B & SE \\
\hline \multicolumn{7}{|c|}{ Transnational marriage (husband from own country of origin) } \\
\hline \multicolumn{7}{|c|}{\begin{tabular}{l|l} 
Group (ref. Turkish 1.5 gen.) &
\end{tabular}} \\
\hline Italian $1^{\text {st }}$ gen. & $-2.58^{\star * *}$ & 0.56 & $-1.98^{\star *}$ & 0.62 & $-2.00^{\star *}$ & 0.62 \\
\hline Italian 1.5 gen. & $-2.62^{\star * *}$ & 0.29 & $-2.37^{* * *}$ & 0.33 & $-2.38^{* * *}$ & 0.33 \\
\hline Italian $2^{\text {nd }}$ gen. & $-2.48^{* * *}$ & 0.29 & $-2.49^{* * *}$ & 0.31 & $-2.54^{* * *}$ & 0.31 \\
\hline Spanish $1^{\text {st }}$ gen. & $-3.32^{* *}$ & 1.24 & $-3.09^{*}$ & 1.25 & $-3.05^{*}$ & 1.25 \\
\hline Spanish 1.5 gen. & $-2.89^{* * *}$ & 0.87 & $-2.96^{* * *}$ & 0.88 & $-2.98^{\star * *}$ & 0.88 \\
\hline Spanish $2^{\text {nd }}$ gen. & $-4.21^{*}$ & 1.81 & $-4.53^{*}$ & 1.81 & $-4.59^{*}$ & 1.81 \\
\hline Greek $1^{\text {st }}$ gen. & $-2.17^{* * *}$ & 0.56 & $-2.18^{* * *}$ & 0.56 & $-2.15^{\star * *}$ & 0.56 \\
\hline Greek 1.5 gen. & $-0.89^{* * *}$ & 0.21 & $-1.12^{* * *}$ & 0.22 & $-1.11^{* \star *}$ & 0.22 \\
\hline Greek $2^{\text {nd }}$ gen. & $-1.63^{* * *}$ & 0.26 & $-1.91^{* * *}$ & 0.28 & $-1.89^{* * *}$ & 0.28 \\
\hline Turkish $1^{\text {st }}$ gen. & 0.08 & 0.15 & 0.03 & 0.15 & 0.04 & 0.16 \\
\hline Turkish $2^{\text {nd }}$ gen. & $-0.51^{* * *}$ & 0.10 & $-0.31^{* *}$ & 0.10 & $-0.30^{* *}$ & 0.10 \\
\hline ex-Yugoslav $1^{\text {st }}$ gen. & $-1.27^{\star \star *}$ & 0.21 & $-1.27^{\star * *}$ & 0.21 & $-1.29^{* * *}$ & 0.21 \\
\hline ex-Yugoslav 1.5 gen. & $-0.68^{\star * *}$ & 0.19 & $-0.88^{* * *}$ & 0.19 & $-0.91^{* \star *}$ & 0.19 \\
\hline ex-Yugoslav $2^{\text {nd }}$ gen. & $-0.67^{\star *}$ & 0.21 & $-0.89^{* * *}$ & 0.22 & $-0.90^{\star * *}$ & 0.22 \\
\hline Age at marriage (cent. 24 yrs.) & $-0.05^{\star \star *}$ & 0.01 & $-0.06^{* * *}$ & 0.01 & $-0.06^{\star * *}$ & 0.01 \\
\hline Marriage Cohort (cent. 1985) & $0.04^{\star * *}$ & 0.01 & $0.05^{\star * *}$ & 0.01 & $0.05^{\star * *}$ & 0.01 \\
\hline Rel. group size & & & $-0.26^{\star * *}$ & 0.06 & $-0.25^{\star \star \star}$ & 0.06 \\
\hline$\underline{\text { Rel. sex ratio }}$ & & & $-0.34^{*}$ & 0.14 & $-0.32^{*}$ & 0.14 \\
\hline \multicolumn{7}{|l|}{ Education (ref.1b) } \\
\hline Not applicable \& no education & & & & & 0.00 & 0.11 \\
\hline 1c (basic voc. training) & & & & & $0.23^{*}$ & 0.10 \\
\hline $2 \mathrm{~b}$ (intermediate general) & & & & & -0.06 & 0.19 \\
\hline 2a (intermediate voc.) & & & & & 0.09 & 0.15 \\
\hline 2c_gen (general maturity) & & & & & -0.25 & 0.40 \\
\hline 2c_voc (voc. maturity) & & & & & -0.20 & 0.35 \\
\hline 3a (lower tertiary) & & & & & 0.03 & 0.76 \\
\hline $3 b$ (higher tertiary) & & & & & 0.27 & 0.48 \\
\hline $\begin{array}{c}\text { Still in school } \\
\end{array}$ & & & & & $-0.87^{\star *}$ & 0.32 \\
\hline Constant & $-0.61^{* * *}$ & 0.06 & 0.12 & 0.16 & 0.05 & 0.16 \\
\hline \multicolumn{7}{|c|}{ Bi-national marriage to a German husband } \\
\hline Group (ref. Turkish 1.5 gen.) & & & & & & \\
\hline Italian $1^{\text {st }}$ gen. & $1.81^{* * *}$ & 0.25 & $1.56^{\star \star *}$ & 0.26 & $1.46^{* * *}$ & 0.27 \\
\hline Italian 1.5 gen. & $1.42^{* * *}$ & 0.21 & $1.20^{* * *}$ & 0.22 & $1.20^{* * *}$ & 0.23 \\
\hline Italian $2^{\text {nd }}$ gen. & $2.16^{* * *}$ & 0.20 & $1.90^{* * *}$ & 0.22 & $1.68^{* * *}$ & 0.22 \\
\hline Spanish $1^{\text {st }}$ gen. & $2.34^{* * *}$ & 0.29 & $2.03^{* * *}$ & 0.31 & $1.87^{* * *}$ & 0.31 \\
\hline Spanish 1.5 gen. & $2.57^{\star * *}$ & 0.28 & $2.21^{* * *}$ & 0.31 & $2.02^{* * *}$ & 0.31 \\
\hline Spanish $2^{\text {nd }}$ gen. & $3.23^{* * *}$ & 0.28 & $2.86^{* * *}$ & 0.30 & $2.50^{* * *}$ & 0.31 \\
\hline Greek $1^{\text {st }}$ gen. & $1.66^{* * *}$ & 0.27 & $1.43^{* * *}$ & 0.28 & $1.20^{* * *}$ & 0.29 \\
\hline Greek 1.5 gen. & $1.46^{\star * *}$ & 0.26 & $1.16^{* * *}$ & 0.28 & $1.02^{* * *}$ & 0.28 \\
\hline Greek $2^{\text {nd }}$ gen. & $1.43^{* * *}$ & 0.26 & $1.10^{\star * *}$ & 0.28 & $0.76^{\star *}$ & 0.28 \\
\hline Turkish $1^{\text {st }}$ gen. & $1.17^{* \star *}$ & 0.24 & $1.05^{\star * *}$ & 0.25 & $0.96^{* * *}$ & 0.25 \\
\hline
\end{tabular}




\begin{tabular}{|c|c|c|c|c|c|c|}
\hline & \multicolumn{2}{|c|}{ Model 1} & \multicolumn{2}{|c|}{ Model 2} & \multicolumn{2}{|c|}{ Model 3} \\
\hline & B & SE & B & SE & B & SE \\
\hline Turkish $2^{\text {nd }}$ gen. & $0.57^{* *}$ & 0.22 & $0.79^{* * *}$ & 0.23 & $0.68^{* *}$ & 0.24 \\
\hline ex-Yugoslav $1^{\text {st }}$ gen. & $2.11^{* * *}$ & 0.20 & $2.11^{* * *}$ & 0.20 & $1.89^{* * *}$ & 0.20 \\
\hline ex-Yugoslav 1.5 gen. & $2.16^{* * *}$ & 0.22 & $1.95^{* * *}$ & 0.23 & $1.75^{* * *}$ & 0.23 \\
\hline ex-Yugoslav $2^{\text {nd }}$ gen. & $2.20^{* * *}$ & 0.24 & $2.04^{* * *}$ & 0.25 & $1.73^{* * *}$ & 0.25 \\
\hline Age at marriage (cent. 24 yrs.) & $0.05^{\star * *}$ & 0.01 & $0.04^{* * *}$ & 0.01 & $0.05^{\star * *}$ & 0.01 \\
\hline Marriage Cohort (cent. 1985) & $0.02^{* * *}$ & 0.00 & $0.03^{* * *}$ & 0.01 & $0.01^{*}$ & 0.01 \\
\hline Rel. group size & & & $-0.27^{* *}$ & 0.09 & $-0.25^{* *}$ & 0.09 \\
\hline Rel. sex ratio & & & 0.05 & 0.03 & 0.02 & 0.03 \\
\hline \multicolumn{7}{|l|}{ Education (ref.1b) } \\
\hline Not applicable \& no education & & & & & $-0.47^{* *}$ & 0.17 \\
\hline 1c (basic voc. training) & & & & & $0.64^{* * *}$ & 0.10 \\
\hline $2 \mathrm{~b}$ (intermediate general) & & & & & $0.49^{*}$ & 0.20 \\
\hline 2a (intermediate voc.) & & & & & $0.93^{* * *}$ & 0.14 \\
\hline 2c_gen (general maturity) & & & & & $1.12^{* * *}$ & 0.29 \\
\hline 2c_voc (voc. maturity) & & & & & $0.99^{* * *}$ & 0.23 \\
\hline 3a (lower tertiary) & & & & & $1.57^{* * *}$ & 0.45 \\
\hline $3 b$ (higher tertiary) & & & & & $1.56^{* * *}$ & 0.31 \\
\hline Still in school & & & & & $0.65^{\star}$ & 0.32 \\
\hline Constant & $-3.09^{* * *}$ & 0.17 & $-2.71^{* * *}$ & 0.22 & $-2.91^{* * *}$ & 0.22 \\
\hline$\chi^{2}$-Wert & \multicolumn{2}{|c|}{1477.76} & \multicolumn{2}{|c|}{1516.64} & \multicolumn{2}{|c|}{1660.50} \\
\hline Mc Fadden-Pseudo- $R^{2}$ & \multicolumn{2}{|c|}{0.148} & \multicolumn{2}{|c|}{0.152} & \multicolumn{2}{|c|}{0.166} \\
\hline $\mathrm{N}$ & \multicolumn{2}{|c|}{5,634} & \multicolumn{2}{|c|}{5,634} & \multicolumn{2}{|c|}{5,634} \\
\hline
\end{tabular}

significance: ${ }^{*} \mathrm{p}<0.05,{ }^{* *} \mathrm{p}<0.01,{ }^{* * *} \mathrm{p}<0.001$

Source: Microcensus Scientific Use Files 1976-2004 (19 files),

When the structural variables are included in Model 2, we find that both have significantly negative effects in accordance with the theoretical expectations: the larger the size of a group in the receiving country and the higher the ratio of men vs. women within a group, the lower the odds of marrying a partner from one's country of origin. Controlling for the opportunity structure in this way, the effect of the marriage cohort increases (compared to Model 1). This means that controlling for changes in the marriage market for conationals in Germany, the net trend towards transnational marriage is even more pronounced. By and large, the two structural variables can not account for the differences between nationalities and generations, as most coefficients do not change very much between Model 1 and Model 2. In Model 3 one finds that, as in the case of men, educational qualifications do not play an important role in explaining the odds of marrying a transnational partner.

Finally, and for the sake of completeness, we briefly want to highlight the most important findings in the lower part of Table $2 b$, which deals with the odds of marrying a German vs. a co-national husband. Controlling only for age at marriage and marriage cohort, Turkish women in all generations have the lowest odds of marrying a German husband. At the other extreme, Spaniards have by far the highest share of intermarriages, followed by ex-Yugoslavs and Italians. Astonishingly, among Turkish females, those who belong to the first generation have even (significantly) higher odds than those who belong to the second. Among Greek and ex-Yugoslav females there are hardly any differences between generations, and they are also not very pronounced in the case of Italians. Only 
Spanish women of the second generation show significantly higher odds of a bi-national marriage than those of the first generation, as one would expect from a general intergenerational assimilation perspective. Net of these differences, we find a significant positive trend in intermarriage over marriage cohorts. The trend is even stronger, once we control for opportunity structure in Model 2. Of the two variables, however, only relative group size has a significant effect in the theoretically expected direction. The structural variables also cannot explain much of the group and generation differences. Model 3 shows that the odds of marrying a German husband tend to increase with higher education. The effects are less pronounced, however, than in the case of men. Nevertheless, education seems important in explaining the trend over marriage cohorts, as the effect lessens notably in Model 3. It also adds a little bit to explaining the group and generation differences; however, the coefficients of the group-by-nationality variables in Model 3 are still remarkable.

\subsection{Group-specific trends over marriage cohorts}

The analyses in the last section have shown that accounting for group and generation differences, the odds that immigrant women will marry a partner from the country of origin rather than a co-national from the receiving society have grown over marriage cohorts. Controlling for the opportunity structure, the trend is even more pronounced. For men no gross trend exists; once controlling for the structural variables, the tendency is slightly negative. The trends in Tables $2 a$ and $2 b$ are general in the sense that the impact of marriage cohorts is assumed to be the same for all nationality groups involved. However, in Figures $1 \mathrm{a}$ and $1 \mathrm{~b}$ we have seen that the patterns over cohorts differ somewhat between the groups involved. Therefore, we re-ran our analyses including group-specific trends, i.e., interactions between nationality groups and marriage cohorts. Table 3 presents the effect of the interaction terms taken from different models.

Model 0 controls only for nationality and age at marriage. Speaking visually, it fits linear trends to the developments in Figure 1a above. We find that among Italians there is a significant decline in the odds of choosing a transnational partner. Except for the exYugoslavs, the trend is also negative among the other groups; however, all coefficients, including that for former Yugoslavs, fail to be significant. In Model 1 we differentiate also by generations within groups, so this analysis is similar to Model 1 in Table 2a above. Now, the amount of the negative coefficient for Italians is, as also for three other groups, slightly reduced. This suggests that the decline in transnational marriage is partly due to the process of intergenerational change. However, it does not seem to be connected to changes in opportunity structures or to processes of structural integration in terms of educational attainment: None of the coefficients changes notably in Model 2 and Model 3. 
Table 3: Effects of the interaction between marriage cohort and nationality, controlled by different variables

\begin{tabular}{|c|c|c|c|c|c|c|c|c|}
\hline \multirow[t]{2}{*}{$\begin{array}{l}\text { Under control of: } \\
\text { (\& age at marriage) }\end{array}$} & \multicolumn{2}{|c|}{$\begin{array}{c}\text { Model } 0 \\
\text { Nationality }\end{array}$} & \multicolumn{2}{|c|}{$\begin{array}{c}\text { Model } 1 \\
\text { Nationality \& } \\
\text { generation }\end{array}$} & \multicolumn{2}{|c|}{$\begin{array}{c}\text { Model } 2 \\
\text { Nationality, genera- } \\
\text { tion, group size \& } \\
\text { sex ratio }\end{array}$} & \multicolumn{2}{|c|}{$\begin{array}{c}\text { Model } 3 \\
\text { Nationality, genera- } \\
\text { tion, group size, sex } \\
\text { ratio \& education }\end{array}$} \\
\hline & B & SE & B & SE & B & SE & B & SE \\
\hline \multicolumn{9}{|l|}{ Men: } \\
\hline \multicolumn{9}{|l|}{ Transnational } \\
\hline Italian & $-0.03^{* * *}$ & 0.01 & $-0.02^{* * *}$ & 0.01 & $-0.02^{* *}$ & 0.01 & $-0.02^{* *}$ & 0.01 \\
\hline Spanish & -0.03 & 0.02 & 0.01 & 0.02 & 0.01 & 0.02 & 0.01 & 0.02 \\
\hline Greek & -0.01 & 0.01 & -0.00 & 0.01 & -0.00 & 0.01 & -0.00 & 0.01 \\
\hline Turkish & -0.01 & 0.00 & 0.00 & 0.00 & -0.01 & 0.01 & -0.01 & 0.01 \\
\hline ex-Yugoslav & 0.01 & 0.01 & 0.01 & 0.01 & 0.01 & 0.01 & 0.01 & 0.01 \\
\hline \multicolumn{9}{|l|}{ Bi-national } \\
\hline Italian & -0.00 & 0.00 & -0.00 & 0.01 & -0.00 & 0.01 & -0.00 & 0.01 \\
\hline Spanish & $0.06^{\star * *}$ & 0.01 & $0.04^{* *}$ & 0.02 & $0.06^{* *}$ & 0.02 & $0.05^{\star *}$ & 0.02 \\
\hline Greek & 0.01 & 0.01 & 0.00 & 0.01 & 0.00 & 0.01 & -0.01 & 0.01 \\
\hline Turkish & $0.02^{* *}$ & 0.01 & $0.03^{* * *}$ & 0.01 & $0.05^{* * *}$ & 0.01 & $0.04^{* * *}$ & 0.01 \\
\hline ex-Yugoslav & $0.04^{* * *}$ & 0.01 & $0.03^{* * *}$ & 0.01 & $0.03^{* * *}$ & 0.01 & $0.03^{* * *}$ & 0.01 \\
\hline \multicolumn{9}{|l|}{ Women: } \\
\hline \multicolumn{9}{|l|}{ Transnational } \\
\hline Italian & 0.03 & 0.02 & 0.02 & 0.02 & -0.02 & 0.03 & -0.02 & 0.03 \\
\hline Spanish & 0.05 & 0.08 & 0.08 & 0.08 & 0.06 & 0.08 & 0.06 & 0.09 \\
\hline Greek & -0.00 & 0.02 & -0.01 & 0.02 & -0.01 & 0.02 & -0.01 & 0.02 \\
\hline Turkish & $0.03^{* * *}$ & 0.01 & $0.04^{* * *}$ & 0.01 & $0.06^{* * *}$ & 0.01 & $0.06^{* * *}$ & 0.01 \\
\hline ex-Yugoslav & $0.05^{\star * *}$ & 0.01 & $0.04^{* * *}$ & 0.01 & $0.04^{* * *}$ & 0.01 & $0.04^{\star * *}$ & 0.01 \\
\hline \multicolumn{9}{|l|}{ Bi-national } \\
\hline Italian & $0.03^{* * *}$ & 0.01 & $0.02^{* *}$ & 0.01 & $0.03^{* *}$ & 0.01 & 0.02 & 0.01 \\
\hline Spanish & $0.08^{* * *}$ & 0.02 & $0.06^{\star * *}$ & 0.02 & $0.06^{* * *}$ & 0.02 & $0.05^{\star *}$ & 0.02 \\
\hline Greek & 0.02 & 0.01 & 0.02 & 0.01 & 0.02 & 0.01 & 0.01 & 0.01 \\
\hline Turkish & $0.05^{* * *}$ & 0.01 & $0.06^{* * *}$ & 0.01 & $0.07^{* * *}$ & 0.01 & $0.07^{* * *}$ & 0.01 \\
\hline ex-Yugoslav & 0.00 & 0.01 & -0.00 & 0.01 & -0.00 & 0.01 & -0.02 & 0.01 \\
\hline
\end{tabular}

significance: $* \mathrm{p}<0.05, * * \mathrm{p}<0.01, * * * \mathrm{p}<0.001$

Source: Microcensus Scientific Use Files 1976-2004 (19 files),

Among all groups of women except Greeks we find positive trends towards a transnational marriage choice. These trends are significant in the case of Turks and of exYugoslavs. Controlling for generations in Model 1, the interaction effect for exYugoslavs slightly decreases, meaning that the surprising fact that ex-Yugoslav women of the second generation, moreso than those of the first and 1.5 generations, are likely to engage in transnational marriages (see Table 2b), accounts for parts of the rise over cohorts. The trend stays stable even when controlling for opportunity structure (Model 2) and educational attainment (Model 3). Among Turkish women the positive trend is even more pronounced when controlling also for generations (Model 1) and opportunity structure (Model 3), i.e., accounting for the fact that there is a decline in the second generation and that the opportunity structure for co-national immigrant partners within Germany has been increasing. Trends in educational attainment do not impact the trends in marriage choice (Model 3). 
The corresponding trends with respect to bi-national marriage are included in Table 3 just for information. As they are not at the focus of our interest, we do not discuss them here any further.

\section{Summary and discussion}

In this paper, we made use of pooled cross-sectional data from the German Microcensus to study transnational marriage among former labour migrants and their descendants in Germany. While available empirical evidence is, with rare exceptions, rather crude and anecdotic, the huge sample size enabled us to contribute to explaining this important phenomeneon with empirical findings that are unique in their scope and their degree of differentiation. Our analyses were guided by four basic expectations, which were anchored in a more general theoretical framework of immigrants' marriage behaviour. Summarizing our results, we want to briefly refer to each of these points in the following, highlighting the relevancy of central findings and indicating some implications for future research.

We could confirm, first, the more or less well-known fact of notable differences between ethnic groups. Not surprisingly, among all five labour migrant groups under consideration, marrying a partner residing in the country of origin is most common among Turks. Transnational marriage choice is also of notable importance among ex-Yugoslavs. It plays only a negligible role, however, among Italians, Spaniards, and Greeks. As outlined in Section 2.2, it would make some sense to attribute these group differences to religion and to legal restrictions on immigration. Within the possibilities given by our data, we can deliver only indirect evidence for this point of view; it is supported insofar as variables related to rivalling explanations, like different opportunity structures or lower structural integration, can not reduce the group differences significantly in multivariate analyses. We consider it a crucial task for future research to test more directly whether religion-based cultural orientations and motivational aspects related to legal immigration restrictions indeed matter, and in how far they are already sufficient explanations. Next to group differences, we also found a notable difference between genders among all groups. Marrying a co-ethnic partner from abroad is by far more common among male immigrants than among female immigrants. This tends to hold even controlling for genderspecific opportunity structures; this gender gap is hard to explain straightforward by the standard approaches, and requires further theoretical elaboration.

Our second focus was on trends of transnational marriage over generations and time (in terms of marriage cohorts). A basic assimilationist perspective would expect declining tendencies, which is in line with the more general framework sketched in Section 2.1. We found that by and large there is a lot of support for this expectation; but the picture needs some important differentiations. Both trends over generations and trends over cohorts are quite visible among immigrant men. Here, only ex-Yugoslavs play an exceptional role. In the case of immigrant women the picture is less clear. Let us disregard Italians, Greeks, and Spaniards for a moment, because their general level of transnational marriage is very low anyway. Among Turkish and ex-Yugoslav women in Germany we find a significant increase over the marriage cohorts. And only when we take this general increase into account does a slight decline over generations appear. Obviously, this immediately raises 
the question of how to explain this general increase. This holds all the more as the increase is not straight linear, but developed in cyclical patterns (see Figure 1b). The assumption that this might be decisively connected to severe changes in the legal conditions for immigration and naturalization during the period under study suggests itself. However, we were not able to adequately test for corresponding period effects within the scope of this paper. This is a further challenging task for future research; within the limits of our analyses we can only state that the general increase is not due to changes in the opportunity structure of the marriage market within Germany.

This leads us to the discussion of our third set of hypotheses. We expected transnational marriage to be partly driven by the opportunity structure, i.e., by the supply of potential co-ethnic spouses in the country of residence. Again, we found only partial support according to gender. Among women, the two variables chosen, group size and sex ratio, show the expected negative sign: This means that the larger the pool of potential partners from one's own national group and of opposite sex residing in Germany, the lower is the likelihood to import a husband from one's country of origin. Among men, the structural features do not seem to be important for the formation of transnational marriages; they only affect the propensity toward intermarriage. It is worth noting that the actual opportunity structure is only roughly captured by the two macro variables used in our analyses. It would certainly be desirable to have a more precise measure of the individual opportunity sets in future research; this includes, among others, more-finely grained information on the daily social foci, as well as information on the transnational social networks of immigrants residing in Germany.

Finally, our fourth focus was the role of structural assimilation. We expected the degree of educational attainment to be negatively linked to the propensity to import a spouse from one's own country of origin. But the data did not support this hypothesis, neither for men nor for women. So we could not replicate the finding of González-Ferrer (2006) that at least among men, the practice of importing spouses is clearly related to low levels of education (González-Ferrer 2006: 10). Nor could we find the contrary either, i.e., positive effects of higher education on transnational marriage, such as those Lievens (1999) observed among Turkish women in Belgium. The absence of any negative correlation between transnational marriage and structural assimilation is perhaps the most striking puzzle after the analyses. It further emphasizes the need for more direct tests of rivalling explanations as already discussed under the first point. Whatever the factor that counteracts the assumed negative impact of education on the propensity toward a transnational partner choice, it has severe consequences for the whole process of intergenerational integration: As spouses from the country of origin possess little social or cultural capital specific to the receiving country (e.g., proficiency in the German language, knowledge of the German educational system), this will decelerate the structural integration of the succeeding generation; it is reasonable to assume that this holds especially in the case of wives coming from abroad, as they are primarily concerned with the upbringing and social education of the offspring.

\section{References}

Alba, R. D., Handl, J. \& Müller, W. (1994). Ethnische Ungleichheit im Deutschen Bildungssystem. Kölner Zeitschrift für Soziologie und Sozialpsychologie, 46 (2), pp. 209-237. 
Alba, R. D. \& Golden, R. M. (1986). Patterns of ethnic marriage in the United States. Social Forces, 65 (1), pp. 202-223.

Aydin, H. (2003). Heiratsmigration bei Türkinnen und Türken. In: A. Goldberg, D. Halm \& M. Sauer (Eds), Migrationsbericht der Stiftung Zentrum für Türkeistudien 2003. Münster: Lit. pp. 227-299.

Beck-Gernsheim, E. (2006). Transnationale Heiratsmuster und transnationale Heiratsstrategien. Soziale Welt, 57 (2), pp. 111-129.

Blau, P. M. (1994). Structural contexts of opportunities. Chicago: The University of Chicago Press.

Blau, P. M., Beeker, C. \& Fitzgerald, K. M. (1984). Intersecting social affiliations and intermarriage. Social Forces, 62 (3), pp. 585-606.

Böcker, A. (1994). Chain migration over legally closed borders: Settled immigrants as bridgeheads and gatekeepers. Netherlands Journal of Social Sciences, 30, pp. 87-106.

Brauns, H., Scherer, S. \& Steinmann, S. (2003). The CASMIN educational classification in international comparative research. In: J. H. P. Hoffmeyer-Zlotnik \& C. Wolf (Eds), Advances in cross-national comparison. A European working book for demographic and socio-economic variables. New York: Kluwer Academic/Plenum Publishers, pp. 196-221.

Coleman, D. A. (1994).Trends in fertility and intermarriage among immigrant populations in Western Europe as measures of integration. Journal of Biosocial Science, 26 (1), pp. 107-136.

Diehl, C. \& Koenig, M. (2009). Religiosität türkischer Migranten im Generationenverlauf: Ein Befund und einige Erklärungsversuche. Zeitschrift für Soziologie 38, (4), pp. 300-320.

Diehl, C. \& Schnell, R. (2006). "Reactive ethnicity" or "assimilation"? Statements, arguments, and first empirical evidence for labor migrants in Germany. International Migration Review, 40 (4), pp. 786-816.

Esser, H. (2008). Spracherwerb und Einreisealter: Die schwierigen Bedingungen der Bilingualität. In F. Kalter (Ed.), Migration und Integration. Wiesbaden: VS Verlag (Sonderheft 48 der Kölner Zeitschrift für Soziologie und Sozialpsychologie), pp. 202-229.

Feld, S. L. (1984). The structured use of personal associates. Social Forces, 62 (3), pp. 640-652.

Feld, S. L. (1981). The focused organization of social ties. American Journal of Sociology, 86 (5), pp. 1015-1035.

Fu, X. \& Heaton, T. B. (2008). Racial and educational homogamy: 1980 to 2000. Sociological Perspectives, 51 (4), pp.735-758.

Gerhards, J. \& Hans, S. (2009). From Hasan to Herbert: Name-giving patterns of immigrant parents between acculturation and ethnic maintenance. American Journal of Sociology, 114 (4), pp. 1102-1128.

Gestring, N., Janßen, A. \& Polat, A. (2006). Prozesse der Integration und Ausgrenzung bei türkischen Migranten der zweiten Generation. Wiesbaden: VS Verlag.

González-Ferrer, A. (2006). Who do immigrants marry? Partner choice among single immigrants in Germany. European Sociological Review, 22 (2), pp. 171-185.

Gordon, M. M. (1964). Assimilation in American life: The role of race, religion, and national origins. New York: Oxford University Press.

Gostomski, C. B. von (2008). Türkische, griechische, italienische und polnische Personen sowie Personen aus den Nachfolgestaaten des ehemaligen Jugoslawien in Deutschland. Erste Ergebnisse der Repräsentativbefragung „Ausgewählte Migrantengruppen in Deutschland 2006/2007" (RAM). Nürnberg: Bundesamt für Migration und Flüchtlinge (Working Paper 11).

Granato, N. \& Kalter, F. (2001). Die Persistenz ethnischer Ungleichheit auf dem deutschen Arbeitsmarkt. Diskriminierung oder Unterinvestition in Humankapital? Kölner Zeitschrift für Soziologie und Sozialpsychologie, 53 (3), pp. 497-520.

Haug, S. (2004). Binationale Ehen und interethnische Partnerschaften in Deutschland: Datenlage und Erklärungsfaktoren. Zeitschrift für Familienforschung, 15 (3), pp. 305-329.

Haug, S. (2006). Interethnische Freundschaften, interethnische Partnerschaften und soziale Integration. Diskurs. Kindheits- und Jugendforschung, Heft 1, pp. 75-91.

Hooghiemstra, E. (2001). Migrants, partner selection and integration: Crossing borders? Journal of Comparative Family Studies, 32 (4), pp. 601-626.

Hwang, S.-S., Saenz, R. \& Aguirre, B. E. (1997). Structural and assimilationist explanations of Asian American intermarriage. Journal of Marriage and Family, 59 (3), pp. 758-772. 
Janßen, A. \& Polat, A. (2006). Soziale Netzwerke türkischer Migrantinnen und Migranten. Aus Politik und Zeitgeschichte, 1-2, pp. 11-24.

Janßen, A. \& Schroedter, J. H. (2007). Kleinräumliche Segregation der ausländischen Bevölkerung in Deutschland: Eine Analyse auf Basis des Mikrozensus. Zeitschrift für Soziologie, 36 (6), pp. 453-472.

Kalmijn, M. (1998). Intermarriage and homogamy: Causes, patterns, trends. Annual Review of Sociology, 24 , pp. 395-421.

Kalmijn, M. (1991). Shifting boundaries: Trends in religious and educational homogamy. American Sociological Review, 56 (6), pp. 786-800.

Kalmijn, M. \& Flap, H. D. (2001). Assortative meeting and mating: Unintended consequences of organized settings for partner choices. Social Forces, 79 (4), pp. 1289-1312.

Kalmijn, M. \& Tubergen, F. van (2006). Ethnic intermarriage in the Netherlands: Confirmations and refutations of accepted insights. European Journal of Population, 22 (4), pp. 371-397.

Kalter, F. \& Granato, N. (2002). Demographic change, educational expansion, and structural assimilation of immigrants. The case of Germany. European Sociological Review, 18 (2), pp. 188-216.

Kalter, F. \& Granato, N. (2007). Educational hurdles on the way to structural assimilation in Germany. In: A. F. Heath \& S. Y. Cheung (Eds), Unequal chances: Ethnic minorities in western labour markets. Oxford: Oxford University Press for the British Academy (Proceedings of the British Academy, Volume 137), pp. 271-319.

Kalter, F., Granato, N. \& Kristen, C. (2007). Disentangling recent trends of the second generation's structural assimilation in Germany. In: S. Scherer, R. Pollak, G. Otte \& M. Gangl (Eds), From origin to destination. Trends and mechanisms in social stratification research. Frankfurt am Main: Campus, pp. 214-245.

Klein, T. (2001). Intermarriage between Germans and foreigners in Germany. Journal of Comparative Family Studies, 32 (3), pp. 325-346.

Kreienbrink, A. \& Rühl, S. (2007). Familiennachzug in Deutschland. Nürnberg: Bundesamt für Migration und Flüchtlinge (Working Paper Nr. 10).

Kristen, C. \& Granato, N. (2007). The educational attainment of the second generation in Germany: Social origins and ethnic inequality. Ethnicities 7 (3), pp. 343-366.

Laitner, J. (1991). Modeling marital connections among family lines. Journal of Political Economy, 99 (6), pp. 1123-1141.

Lieberson, S. \& Waters, M. C. (1988). From many strands: Ethnic and racial groups in contemporary America. New York: Russell Sage Foundation.

Lievens, J. (1999). Family-forming migration from Turkey and Morocco to Belgium: The demand for marriage partners from the countries of origin. International Migration Review, 33 (3), pp. 717-744.

Lievens, J. (1998). Interethnic marriage: Bringing in the context through multilevel modelling. European Journal of Population 14 (2), pp. 117-155.

Merton, R. K. (2000). Intermarriage and the social structure: Fact and theory. In: W. Sollos (Ed.), Interracialism. Black-white intermarriage in American history, literature, and law. Oxford: University Press, pp. 473-492.

Model, S. \& Fisher, G. (2002). Unions between black and whites: England and the U.S. compared. Ethnic and Racial Studies, 25 (5), pp. 728-754.

Nauck, B. (2007). Immigrant families in Germany. Family change between situational adaption, acculturation, segregation and remigration. Zeitschrift für Familienforschung, 19 (1), pp. 34-54.

Nauck, B. (2001). Generationsbeziehungen und Heiratsregimes - theoretische Überlegungen zur Struktur von Heiratsmärkten und Partnerwahlprozessen am Beispiel der Türkei und Deutschland. In: T. Klein (Ed.), Partnerwahl und Heiratsmuster. Sozialstrukturelle Voraussetzungen der Liebe. Opladen: Leske + Budrich, pp. 35-55.

Pagnini, D. L. \& Morgan, S. P. (1990). Intermarriage and social distance among U.S. immigrants at the turn of the century. American Journal of Sociology, 96 (2), pp. 405-432.

Reniers, G. (2001). The post-migration survival of traditional marriage patterns: Consanguineous marriages among Turks and Moroccans in Belgium. Journal of Comparative Family Studies, 32 (1), pp. $21-45$. 
Qian, Z. (1997). Breaking the racial barriers: Variations in interracial marriage between 1980 and 1990. Demography, 34 (2), pp. 263-276.

Schroedter, J. H. (2006). Binationale Ehen in Deutschland. Wirtschaft und Statistik 4, pp. 419-431.

Schroedter, J. H. (2008). Bildung. In: A. Lengerer, J. H. Schroedter, M. Boehle, T. Hubert \& C. Wolf (Eds), Harmonisierung der Mikrozensen 1962 bis 2005. Version 2. GESIS-Methodenbericht Nr. 12, pp. F1-F50.

Schroedter, J. H. \& Kalter, F. (2008). Binationale Ehen in Deutschland. Trends und Mechanismen der sozialen Assimilation. In: F. Kalter (Ed.), Migration und Integration. Wiesbaden: VS Verlag (Sonderheft 48 der Kölner Zeitschrift für Soziologie und Sozialpsychologie), pp. 351-379.

Straßburger, G. (2001). Transstate ties of the second generation. Marriages of Turks in Germany.Ankara \& Bremen: Universität Bremen, Institut für Interkulturelle und Internationale Studien/Iktisadi ve Idar Blilimler Fakütesi ODTÜ Ankara (Summer Institute working paper 2001/07).

Straßburger, G. (2003). Heiratsverhalten und Partnerwahl im Einwanderungskontext. Eheschließungen der zweiten Migrantengeneration türkischer Herkunft. Würzburg: Ergon Verlag.

Timmerman, C. (2006). Gender dynamics in the context of Turkish marriage migration: The case of Belgium. Turkish Studies, 7 (1), pp. 125-143.

Tubergen, F. van \& Maas, I. (2007). Ethnic intermarriage among immigrants in the Netherlands: An analysis of population data. Social Science Research, 36 (3), pp. 1065-1086.

Wildsmith, E., Gutmann, M. P. \& Gratton, B. (2003). Assimilation and intermarriage for U.S. immigrant groups, 1880-1990. History of the Family, 8 (4), pp. 563-584.

Submitted on/Eingereicht am: 21.04.2009

Accepted on/Angenommen am: 28.01.2010

Addresses of the authors/Anschriften des Autors und der Autorin:

Prof. Dr. Frank Kalter

Lehrstuhl für Allgemeine Soziologie

Universität Mannheim

Seminargebäude A5

D-68131 Mannheim

Germany

E-mail:kalter@uni-mannheim.de

Julia H. Schroedter, Diplom-Sozialwissenschaftlerin

(corresponding author/Korrespondenzautorin)

German Microdata Lab

GESIS - Leibniz-Institut für Sozialwissenschaften

$\mathrm{B} 2,1$

D-68159 Mannheim

Germany

E-mail: julia.schroedter@gesis.org 


\section{Appendix:}

Table 4a: Descriptive statistics of dependent and independent variables for men by nationality and generation (means or percentages in columns)

\begin{tabular}{|c|c|c|c|c|c|c|c|c|c|c|c|c|c|c|c|}
\hline & \multicolumn{3}{|c|}{ Italian } & \multicolumn{3}{|c|}{ Spanish } & \multicolumn{3}{|c|}{ Greek } & \multicolumn{3}{|c|}{ Turkish } & \multicolumn{3}{|c|}{ ex-Yugoslav } \\
\hline & $1^{\mathrm{st}}$ & 1.5 & $2^{\text {nd }}$ & $1^{\text {st }}$ & 1.5 & $2^{\text {nd }}$ & $1^{\text {st }}$ & 1.5 & $2^{\text {nd }}$ & $1^{\text {st }}$ & 1.5 & $2^{\text {nd }}$ & $1^{\text {st }}$ & 1.5 & $2^{\text {nd }}$ \\
\hline & gen. & gen. & gen. & gen. & gen. & gen. & gen. & gen. & gen. & gen. & gen. & gen. & gen. & gen. & gen. \\
\hline \multicolumn{16}{|l|}{ Type of marriage } \\
\hline Transnational marriage & 21.6 & 16.5 & 5.4 & 22.9 & 10.4 & 3.7 & 21.1 & 21.6 & 10.7 & 49.6 & 55.4 & 39.8 & 31.2 & 32.2 & 24.6 \\
\hline Marriage to a co-national & 31.0 & 42.8 & 39.2 & 40.3 & 46.0 & 34.0 & 53.6 & 60.9 & 56.0 & 37.4 & 39.0 & 50.1 & 47.6 & 41.0 & 44.7 \\
\hline Marriage to a German & 47.4 & 40.7 & 55.4 & 36.8 & 43.7 & 62.3 & 25.3 & 17.5 & 33.3 & 13.0 & 5.7 & 10.1 & 21.2 & 26.8 & 30.7 \\
\hline \multicolumn{16}{|l|}{ Age at marriage } \\
\hline Mean & 30.4 & 24.8 & 25.6 & 32.0 & 24.5 & 25.8 & 32.7 & 24.7 & 25.1 & 32.9 & 22.0 & 22.0 & 33.1 & 24.3 & 24.8 \\
\hline \multicolumn{16}{|l|}{ Year of marriage } \\
\hline Mean: $19 .$. & 77 & 80 & 86 & 75 & 79 & 87 & 77 & 83 & 89 & 82 & 86 & 91 & 81 & 87 & 91 \\
\hline \multicolumn{16}{|l|}{ Relative group size } \\
\hline Mean & 1.06 & 0.93 & 0.91 & 0.51 & 0.25 & 0.21 & 0.64 & 0.36 & 0.43 & 1.11 & 2.04 & 3.01 & 1.28 & 0.79 & 1.10 \\
\hline \multicolumn{16}{|l|}{ Relative sex ratio } \\
\hline Mean & 0.32 & 0.47 & 0.62 & 0.48 & 0.74 & 1.05 & 0.74 & 1.01 & 0.93 & 0.95 & 1.13 & 1.12 & 1.20 & 1.11 & 1.19 \\
\hline \multicolumn{16}{|l|}{ Educational attainment } \\
\hline $\begin{array}{l}\text { Not applicable \& } \\
\text { no education }\end{array}$ & 10.3 & 10.6 & 6.1 & 11.4 & 3.2 & 3.6 & 7.5 & 5.0 & 5.7 & 16.1 & 12.9 & 7.6 & 6.1 & 6.3 & 6.2 \\
\hline 1b (general elementary edu- & & & & & & & & & & & & & & & \\
\hline cation) & 42.3 & 47.0 & 24.6 & 41.8 & 32.1 & 12.6 & 43.6 & 41.9 & 22.1 & 36.9 & 43.5 & 29.5 & 25.6 & 25.3 & 16.1 \\
\hline 1c (basic vocational training) & 34.3 & 32.7 & 50.9 & 30.4 & 47.4 & 55.9 & 21.2 & 38.5 & 36.4 & 23.2 & 32.7 & 41.3 & 46.4 & 55.3 & 43.7 \\
\hline 2b (intermediate general) & 3.0 & 2.6 & 0.8 & 2.0 & 2.0 & 3.5 & 4.0 & 1.6 & 4.1 & 3.7 & 2.6 & 2.6 & 1.8 & 1.1 & 1.8 \\
\hline 2a (intermediate vocational) & 6.6 & 5.2 & 11.7 & 5.6 & 9.3 & 14.0 & 6.2 & 8.4 & 17.4 & 6.4 & 4.9 & 10.8 & 10.6 & 7.5 & 20.8 \\
\hline 2c_gen (general maturity) & 0.4 & 0.3 & 0.4 & 1.0 & 0.6 & 1.3 & 4.1 & 1.4 & 2.1 & 3.1 & 0.6 & 1.2 & 1.2 & 1.2 & 1.4 \\
\hline 2c_voc (vocational maturity) & 1.3 & 0.4 & 2.5 & 3.3 & 2.8 & 2.4 & 5.1 & 1.4 & 6.0 & 3.9 & 0.9 & 2.1 & 4.4 & 1.6 & 3.9 \\
\hline 3a (lower tertiary) & 0.8 & 0.4 & 1.3 & 1.3 & 0.8 & 3.3 & 2.4 & 0.6 & 3.1 & 1.9 & 0.6 & 0.7 & 1.5 & 0.5 & 1.0 \\
\hline 3b (higher tertiary) & 0.8 & 0.4 & 0.9 & 2.8 & 1.1 & 1.5 & 5.3 & 0.6 & 2.0 & 3.7 & 0.2 & 0.8 & 2.3 & - & 1.3 \\
\hline Still in school & 0.3 & 0.3 & 0.9 & 0.5 & 0.8 & 2.0 & 0.7 & 0.7 & 1.0 & 1.1 & 1.1 & 3.4 & 0.3 & 1.3 & 3.7 \\
\hline Total & 1,433 & 672 & 298 & 222 & 110 & 79 & 454 & 248 & 134 & 1,190 & 2,111 & 894 & 1,025 & 235 & 134 \\
\hline
\end{tabular}

Source: Microcensus Scientific Use Files 1976-2004 (19 files) 
Table $4 b$ : Descriptive statistics of dependent and independent variables for women by nationality and generation (means or percentages in columns)

\begin{tabular}{|c|c|c|c|c|c|c|c|c|c|c|c|c|c|c|c|}
\hline & \multicolumn{3}{|c|}{ Italian } & \multicolumn{3}{|c|}{ Spanish } & \multicolumn{3}{|c|}{ Greek } & \multicolumn{3}{|c|}{ Turkish } & \multicolumn{3}{|c|}{ ex-Yugoslav } \\
\hline & $1^{\text {st }}$ & 1.5 & $2^{\text {nd }}$ & $1^{\text {st }}$ & 1.5 & $2^{\text {nd }}$ & $1^{\text {st }}$ & 1.5 & $2^{\text {nd }}$ & $1^{\text {st }}$ & 1.5 & $2^{\text {nd }}$ & $1^{\text {st }}$ & 1.5 & $2^{\text {nd }}$ \\
\hline & gen. & gen. & gen. & gen. & gen. & gen. & gen. & gen. & gen. & gen. & gen. & gen. & gen. & gen. & gen. \\
\hline \multicolumn{16}{|l|}{ Type of marriage } \\
\hline Transnational marriage & 1.8 & 2.7 & 3.3 & 0.8 & 1.5 & 0.4 & 2.4 & 13.1 & 8.9 & 25.3 & 36.4 & 29.5 & 5.7 & 15.5 & 18.9 \\
\hline Marriage to a co-national & 70.8 & 82.8 & 67.9 & 65.4 & 65.1 & 45.5 & 73.3 & 73.4 & 74.7 & 61.6 & 60.9 & 65.0 & 60.6 & 58.7 & 54.4 \\
\hline Marriage to a German & 27.5 & 14.5 & 28.8 & 33.9 & 33.4 & 54.1 & 24.3 & 13.6 & 16.4 & 13.1 & 2.7 & 5.6 & 33.7 & 25.7 & 26.7 \\
\hline \multicolumn{16}{|l|}{ Age at marriage } \\
\hline Mean & 31.3 & 21.4 & 22.3 & 30.3 & 22.0 & 22.5 & 31.7 & 20.4 & 21.4 & 31.2 & 20.8 & 20.0 & 32.0 & 22.4 & 22.4 \\
\hline \multicolumn{16}{|l|}{ Year of marriage } \\
\hline Mean: 19.. & 80 & 79 & 86 & 76 & 78 & 85 & 77 & 79 & 88 & 82 & 85 & 90 & 81 & 85 & 90 \\
\hline \multicolumn{16}{|l|}{ Relative group size } \\
\hline Mean & 0.97 & 0.95 & 0.88 & 0.53 & 0.28 & 0.22 & 0.58 & 0.38 & 0.43 & 0.96 & 1.66 & 2.59 & 1.33 & 0.78 & 1.02 \\
\hline \multicolumn{16}{|l|}{ Relative sex ratio } \\
\hline Mean & 3.93 & 2.62 & 2.49 & 2.77 & 1.84 & 1.20 & 1.51 & 1.18 & 1.11 & 1.19 & 0.93 & 0.90 & 0.86 & 1.00 & 0.88 \\
\hline \multicolumn{16}{|l|}{ Educational attainment } \\
\hline $\begin{array}{l}\text { Not applicable \& } \\
\text { no education }\end{array}$ & 11.6 & 13.5 & 6.8 & 8.3 & 4.0 & 3.0 & 10.3 & 8.7 & 6.5 & 23.5 & 17.9 & 12.2 & 8.6 & 6.9 & 7.5 \\
\hline \multicolumn{16}{|l|}{ 1b (general elementary edu- } \\
\hline cation) & 50.1 & 60.8 & 33.8 & 55.5 & 49.2 & 18.3 & 55.0 & 55.3 & 28.4 & 45.2 & 54.5 & 45.5 & 46.9 & 38.0 & 20.5 \\
\hline 1c (basic vocational training) & 20.5 & 18.2 & 31.4 & 20.1 & 25.6 & 40.2 & 12.9 & 20.5 & 23.7 & 14.4 & 17.2 & 19.5 & 25.8 & 34.3 & 32.4 \\
\hline $2 \mathrm{~b}$ (intermediate general) & 4.7 & 2.6 & 3.6 & 1.3 & 6.4 & 6.5 & 4.2 & 4.4 & 6.8 & 5.3 & 3.3 & 5.6 & 3.2 & 4.8 & 3.6 \\
\hline 2a (intermediate vocational) & 5.4 & 3.1 & 18.2 & 5.0 & 9.4 & 22.6 & 2.7 & 6.3 & 15.0 & 4.0 & 4.3 & 9.3 & 8.3 & 11.2 & 23.4 \\
\hline 2c_gen (general maturity) & 2.1 & 0.4 & 1.0 & 2.5 & 0.7 & 2.0 & 3.1 & 1.8 & 4.7 & 1.5 & 0.6 & 1.4 & 1.6 & 0.8 & 1.1 \\
\hline 2c_voc (vocational maturity) & 2.6 & 0.4 & 2.9 & 2.5 & 3.0 & 3.7 & 3.9 & 1.0 & 8.4 & 1.7 & 0.5 & 1.4 & 2.7 & 2.1 & 5.9 \\
\hline 3a (lower tertiary) & 0.8 & 0.3 & 0.7 & 0.8 & 0.3 & 0.6 & 0.7 & 0.4 & 1.4 & 0.6 & 0.1 & 0.4 & 0.8 & 0.1 & 1.1 \\
\hline $3 b$ (higher tertiary) & 1.6 & 0.4 & 1.1 & 2.2 & 0.3 & 1.8 & 6.2 & 0.1 & 2.0 & 2.8 & 0.3 & 0.5 & 1.7 & 0.5 & 0.9 \\
\hline Still in school & 0.7 & 0.4 & 0.5 & 1.8 & 1.1 & 1.2 & 1.1 & 1.5 & 3.1 & 1.1 & 1.4 & 4.3 & 0.4 & 1.5 & 3.7 \\
\hline Total & 184 & 487 & 392 & 89 & 90 & 82 & 144 & 226 & 196 & 346 & 1,405 & 978 & 562 & 267 & 186 \\
\hline
\end{tabular}

Source: Microcensus Scientific Use Files 1976-2004 (19 files) 